\title{
Silica-Supported Phosphonic Acids as Thermally and Oxidatively Stable Organic Acid Sites
}

\author{
Alexandre Charmot, ${ }^{1}$ Andrew Solovyov, ${ }^{1}$ Antonio G. DiPasquale, ${ }^{2}$ Alexander Katz ${ }^{1, *}$ \\ ${ }^{1}$ Department of Chemical and Biomolecular Engineering, University of California at Berkeley, \\ Berkeley, CA 94720-1462 \\ ${ }^{2}$ X-ray Crystallography Facility, University of California, Berkeley, California 94720
}

\section{Supplementary Information:}

Figure 1: FTMS-ESI spectrum of purified $\mathbf{C 3}$ compound ........................................................................ 3

Figure 2: FTMS-ESI spectrum of purified $\mathbf{C 4}$ compound ...................................................................... 3

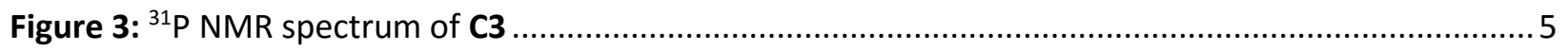

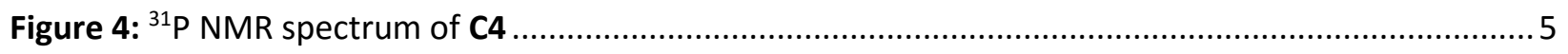

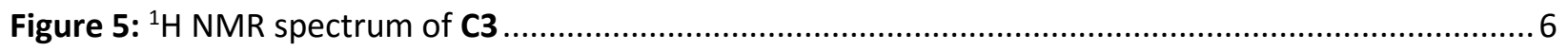

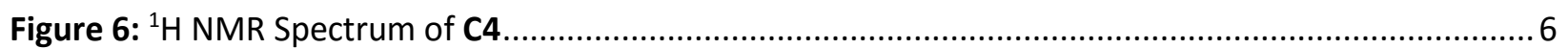

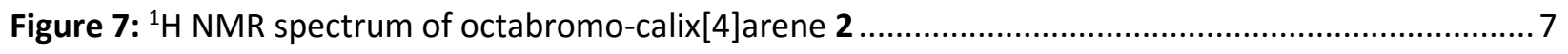

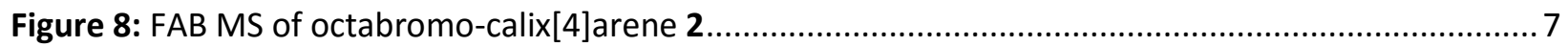

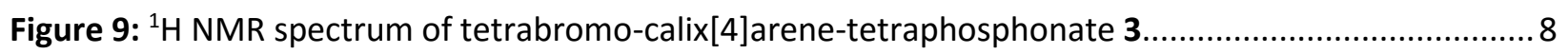

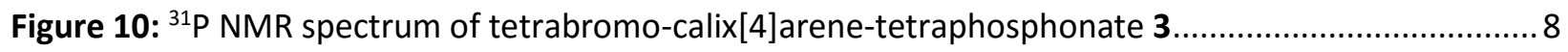

Figure 11: ESI MS spectrum of tetrabromo-calix[4]arene-tetraphosphonate 3 ...................................... 9

Figure 12: ${ }^{1} \mathrm{H}$ NMR spectrum of calix[4]arene-octaphosphonate 4 ................................................... 9

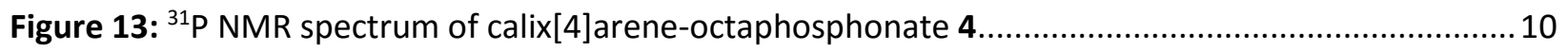

Figure 14: ESI MS spectrum of calix[4]arene-octaphosphonate 4 .................................................... 10

Figure 15: ${ }^{1} \mathrm{H}$ NMR spectrum of calix[4]arene-octaphosphonic acid 5................................................. 11

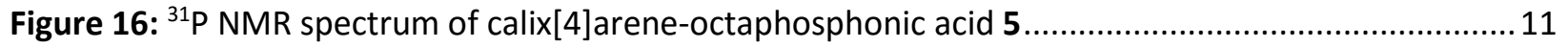

Figure 17: ESI MS spectrum of calix[4]arene octaphosphonic acid 5 ................................................ 12

Figure 18: TGA isotherm analysis of DIPA adsorption on Selecto silica ..............................................13

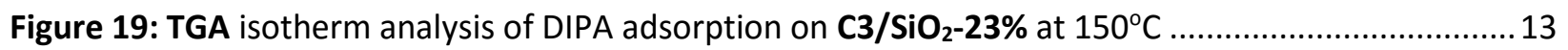

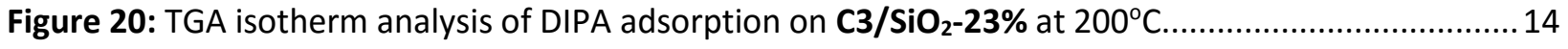

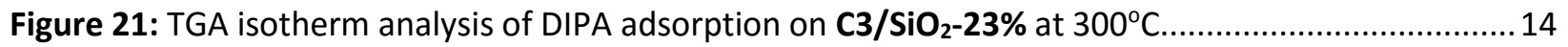

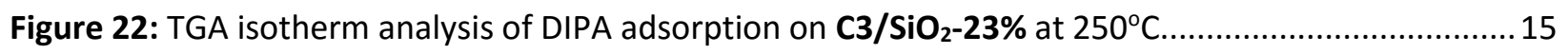

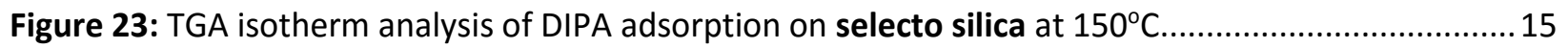

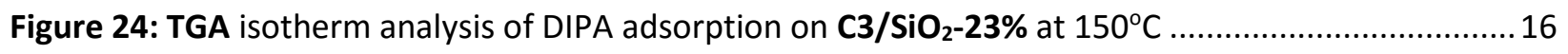

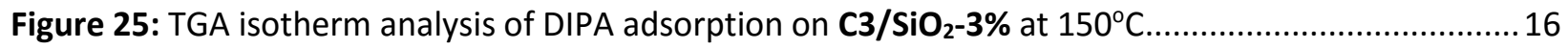

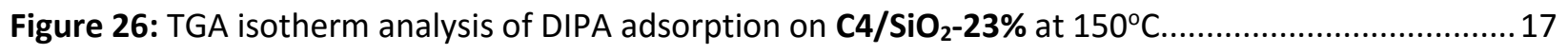

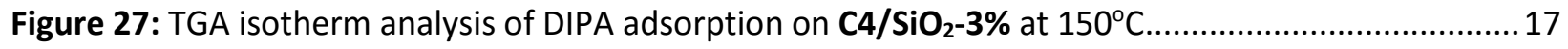

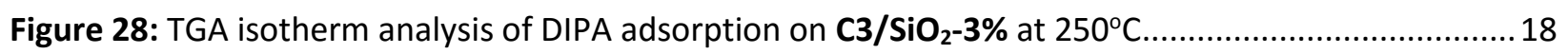

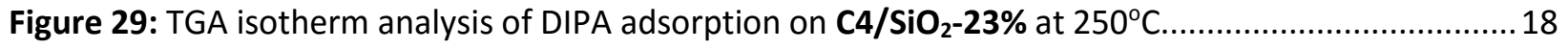




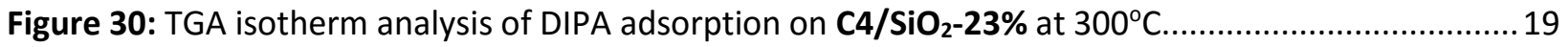

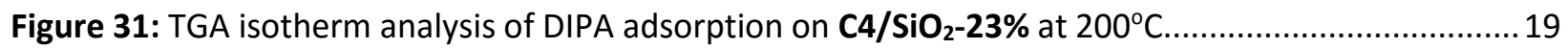

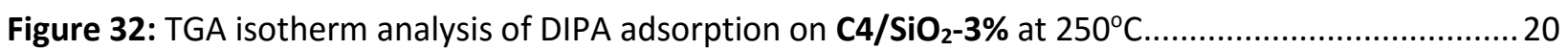

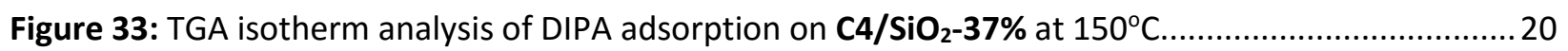

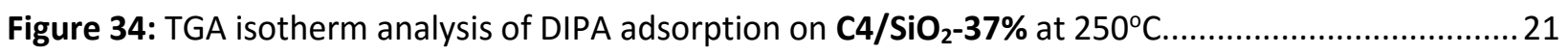

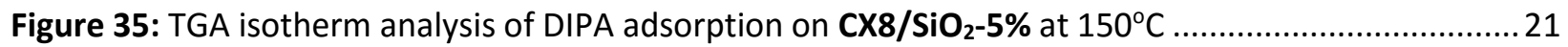

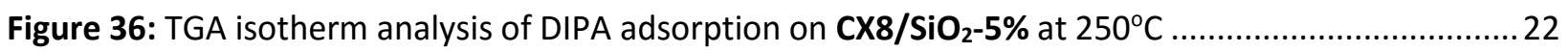

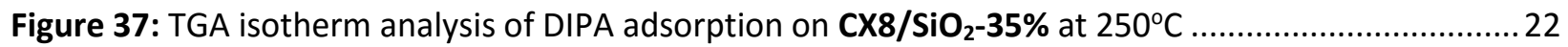

Figure 38: TGA isotherm analysis of DIPA adsorption on $\mathbf{C X 8} / \mathrm{SiO}_{2}-35 \%$ at $200^{\circ} \mathrm{C}$...................................23

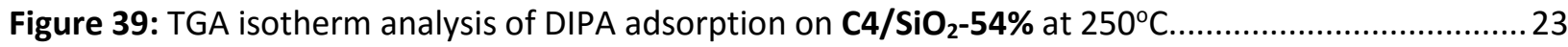

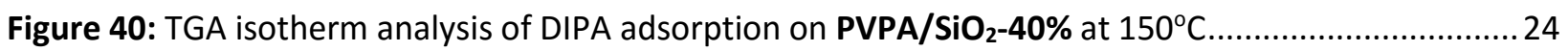

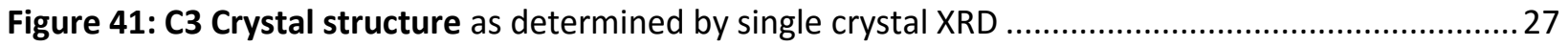

Figure 42a: C3 Crystal structure as determined by single crystal XRD w/ hydrogen bonds highlighted...30

Figure 42b: C4 Crystal structure as determined by single crystal XRD w/ hydrogen bonds highlighted...31

Figure 43: Absorbance of $\mathrm{H}_{3} \mathrm{PO}_{4}, \mathrm{C} 4 / \mathrm{SiO}_{2}-37 \%$, $\mathrm{PVPA} / \mathrm{SiO}_{2}-40 \%$, and $\mathrm{NaH}_{2} \mathrm{PO}_{4}$ treated with an excess of pyridine and degassed overnight at room temperature under vacuum. The background corresponding to the untreated material is subtracted. $\mathrm{H}_{3} \mathrm{PO}_{4}$ spectra is divided 5 fold

Figure 44: TGA spectra coupled with MS spectroscopy for the samples PVPA/SiO $\mathbf{2}_{\mathbf{2}} \mathbf{3 \%}$, during heating at $5^{\circ} \mathrm{C} \cdot \mathrm{min}^{-1}$. The bold line represents TGA spectra and corresponds to the left axis, whereas the thin line in blue, red and green corresponds MS channels corresponding to the molecular mass $17.97\left(\mathrm{H}_{2} \mathrm{O}\right), 27.93$ $\left(\mathrm{CO}, \mathrm{CO}_{2}\right)$ and $43.91\left(\mathrm{CO}_{2}\right)$ respectively.

Figure 1: TGA spectra coupled with MS spectroscopy for the samples PVPA/SiO2-3\%, during heating at $5^{\circ} \mathrm{C} \cdot \mathrm{min}^{-1}$. The bold line represents TGA spectra and corresponds to the left axis, whereas the thin line in blue, red and green corresponds MS channels corresponding to the molecular mass $17.97\left(\mathrm{H}_{2} \mathrm{O}\right), 27.93\left(\mathrm{CO}, \mathrm{CO}_{2}\right)$ and $43.91\left(\mathrm{CO}_{2}\right)$ respectively. .................36 Figure 46: TGA isotherm analysis of DIPA adsorption on $\mathrm{C} 4 / \mathrm{SiO} 2-37 \%$ at $150{ }^{\circ} \mathrm{C}$, after $14.5 \mathrm{~h}$ pre-treatment at $300 \mathrm{oC}(\mathrm{t} 36)$. The arrow correspond to the time of base probe injection. .37 


\section{C3, C4 Masse spectroscopy}

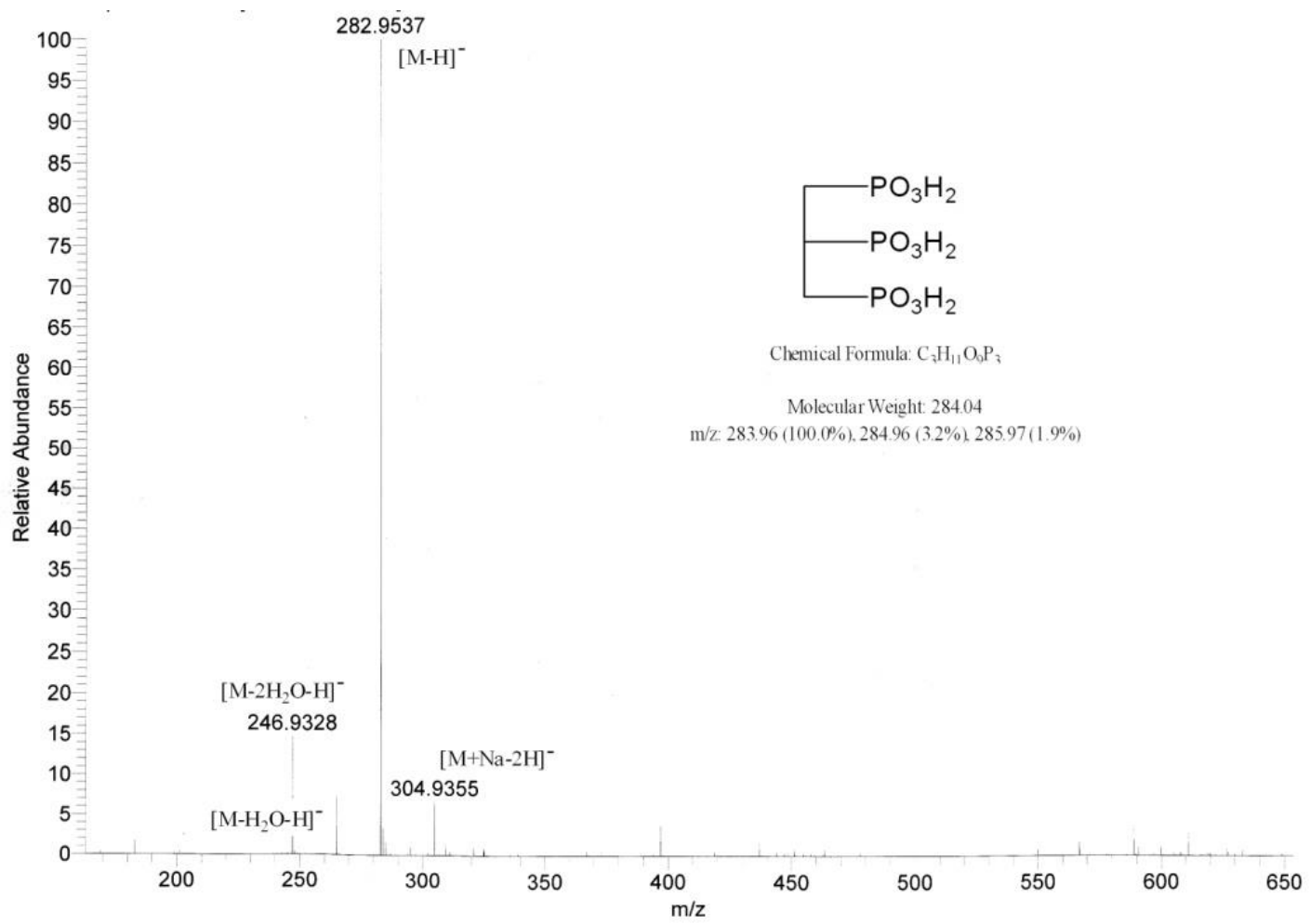

Figure 2: FTMS-ESI spectrum of purified C3 compound

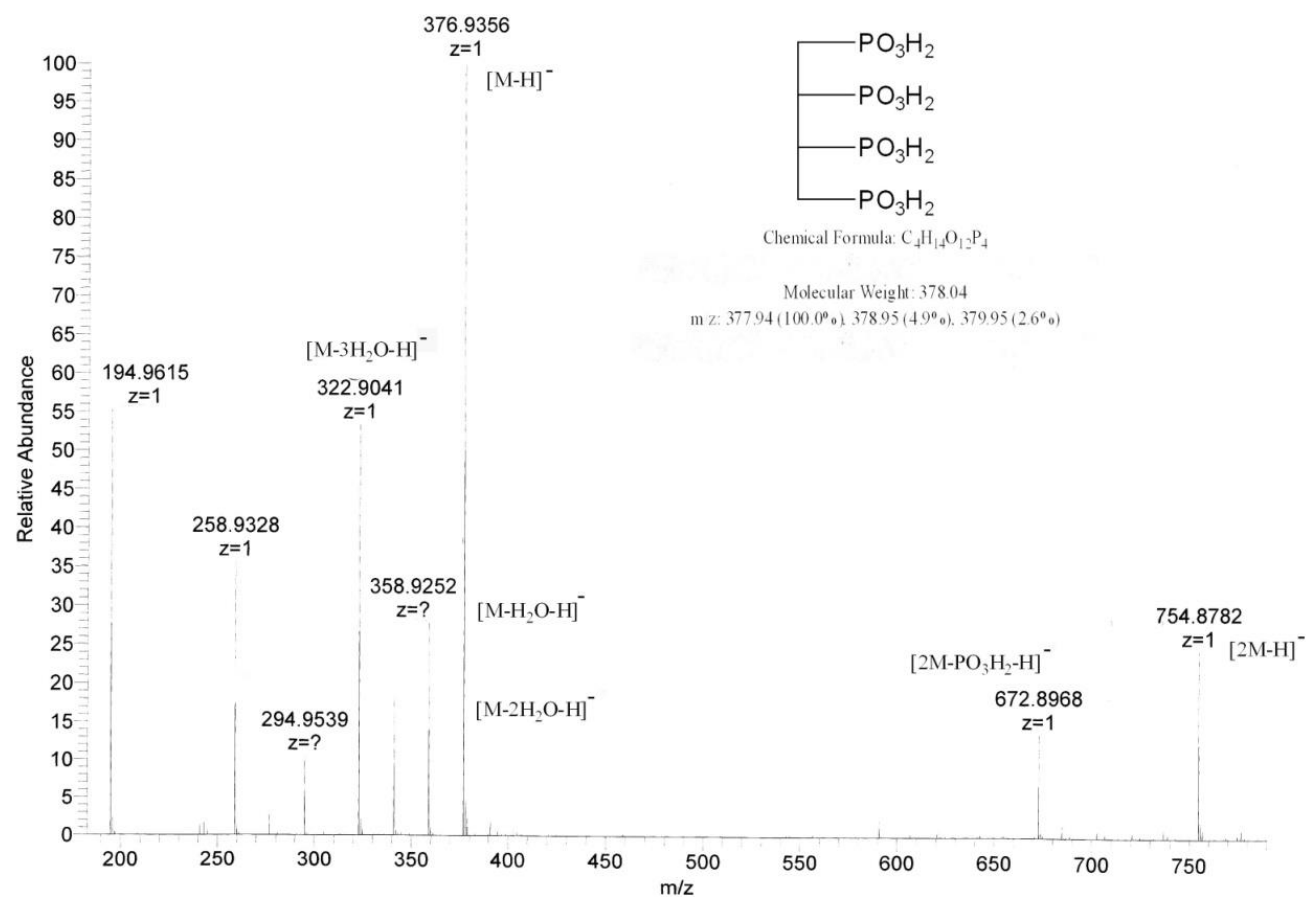

Figure 3: FTMS-ESI spectrum of purified C4 compound 


\section{H and 31P NMR spectroscopy of C3, C4}

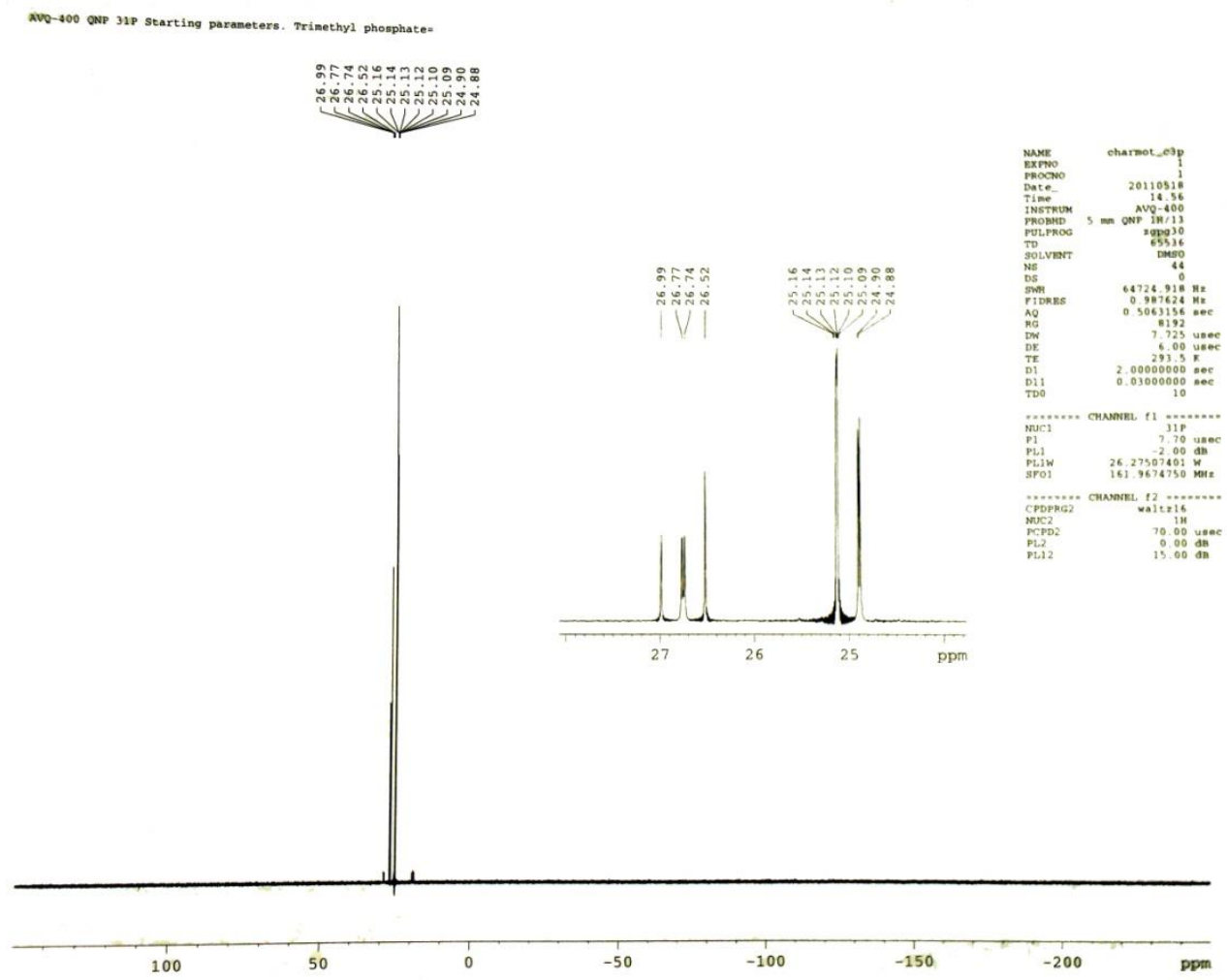

Figure 4: ${ }^{31} \mathrm{P}$ NMR spectrum of $\mathrm{C3}$

AVQ-400 ONP $31 P$ startin

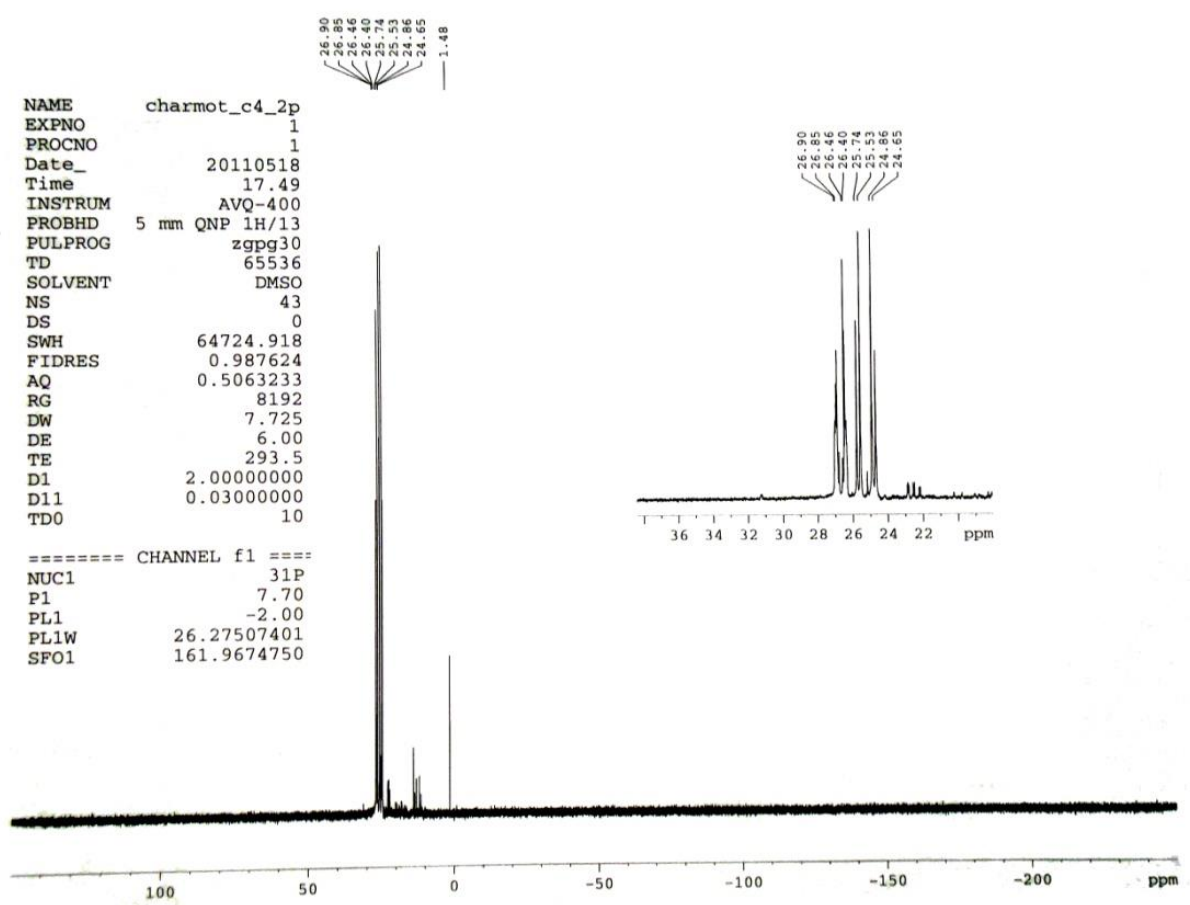

Figure 5: ${ }^{31} \mathrm{P}$ NMR spectrum of $\mathrm{C4}$ 


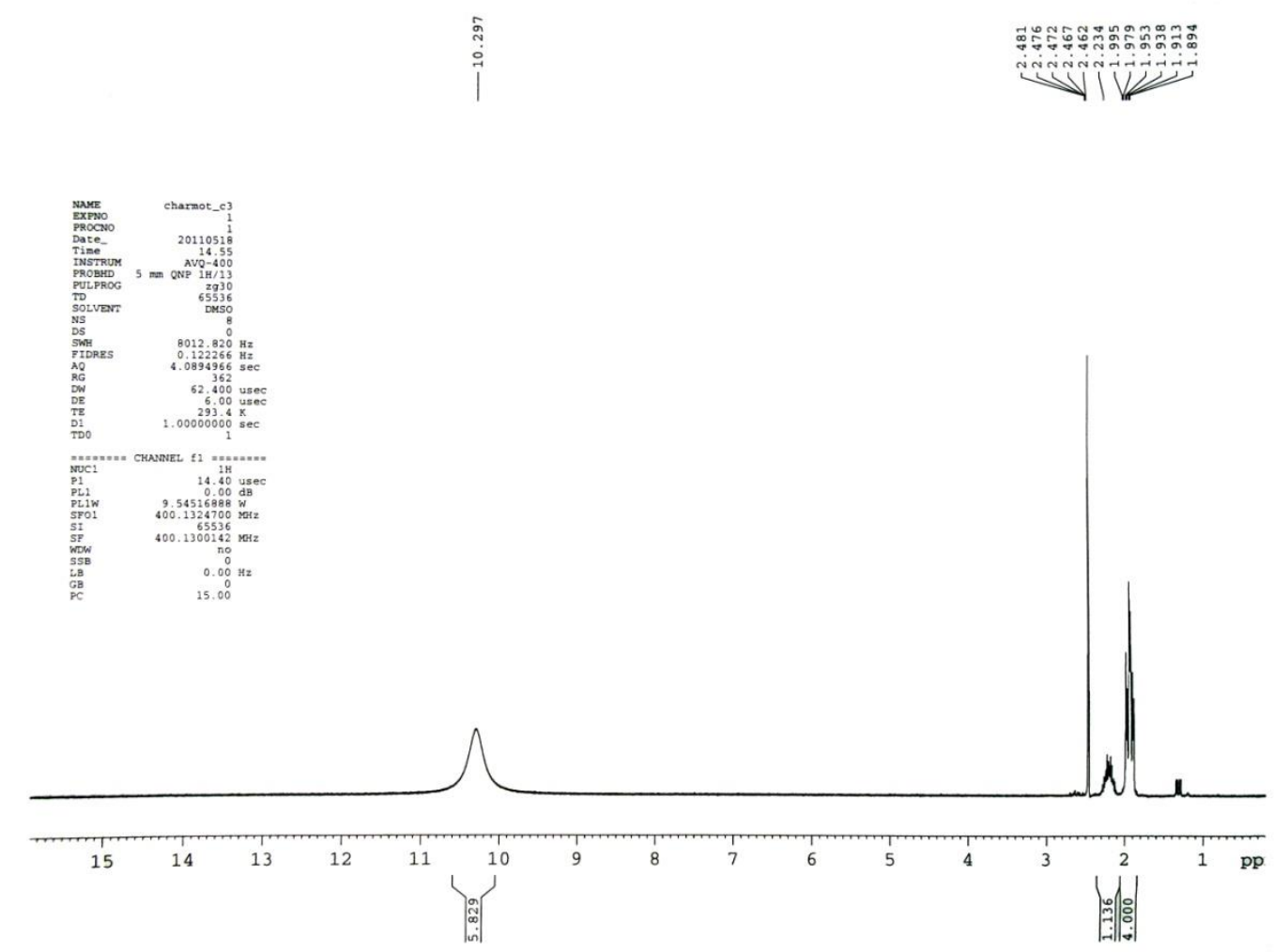

Figure 6: ${ }^{1} \mathrm{H}$ NMR spectrum of $\mathrm{C3}$

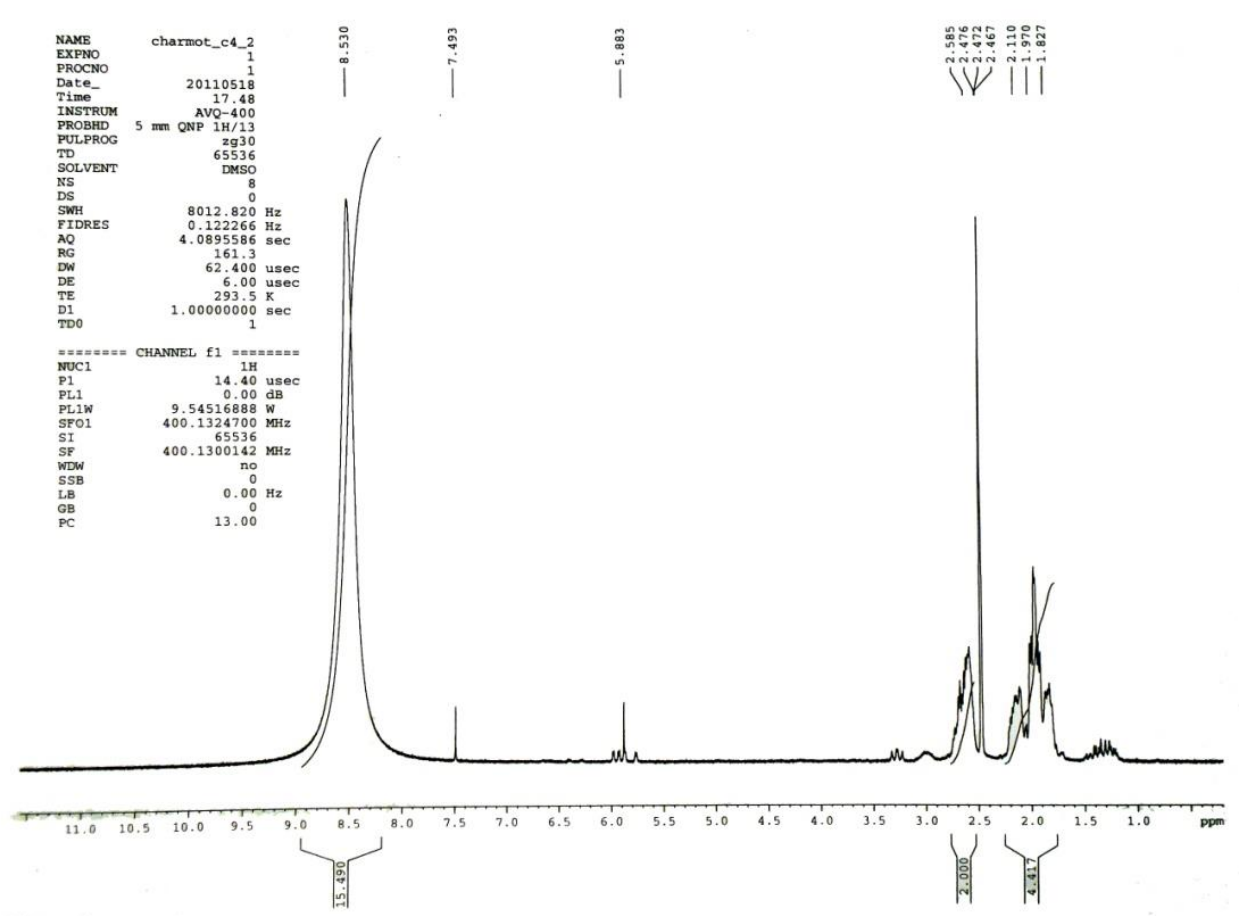

Figure 7: ${ }^{1} \mathrm{H}$ NMR Spectrum of $\mathrm{C4}$ 


\section{Caracterization of CX8 and precursors}
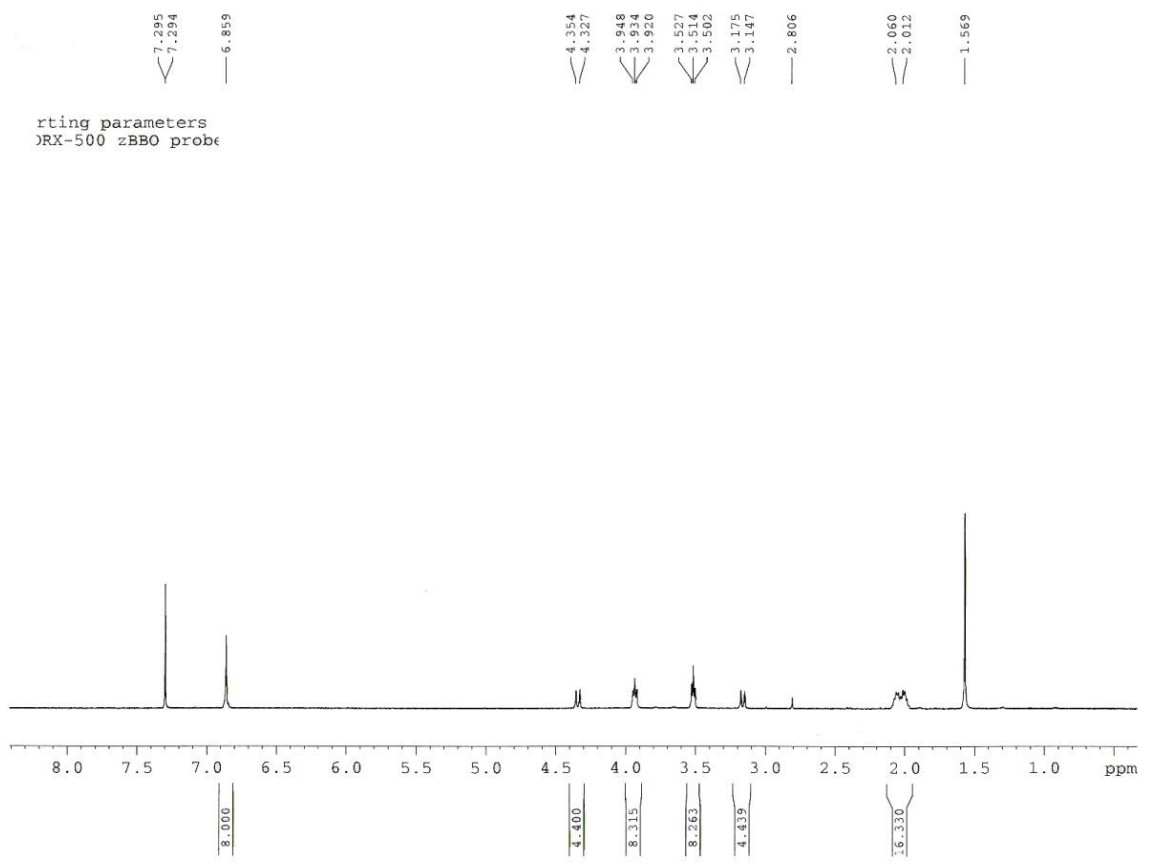

Figure 8: ${ }^{1} \mathrm{H}$ NMR spectrum of octabromo-calix[4]arene $\mathbf{2}$

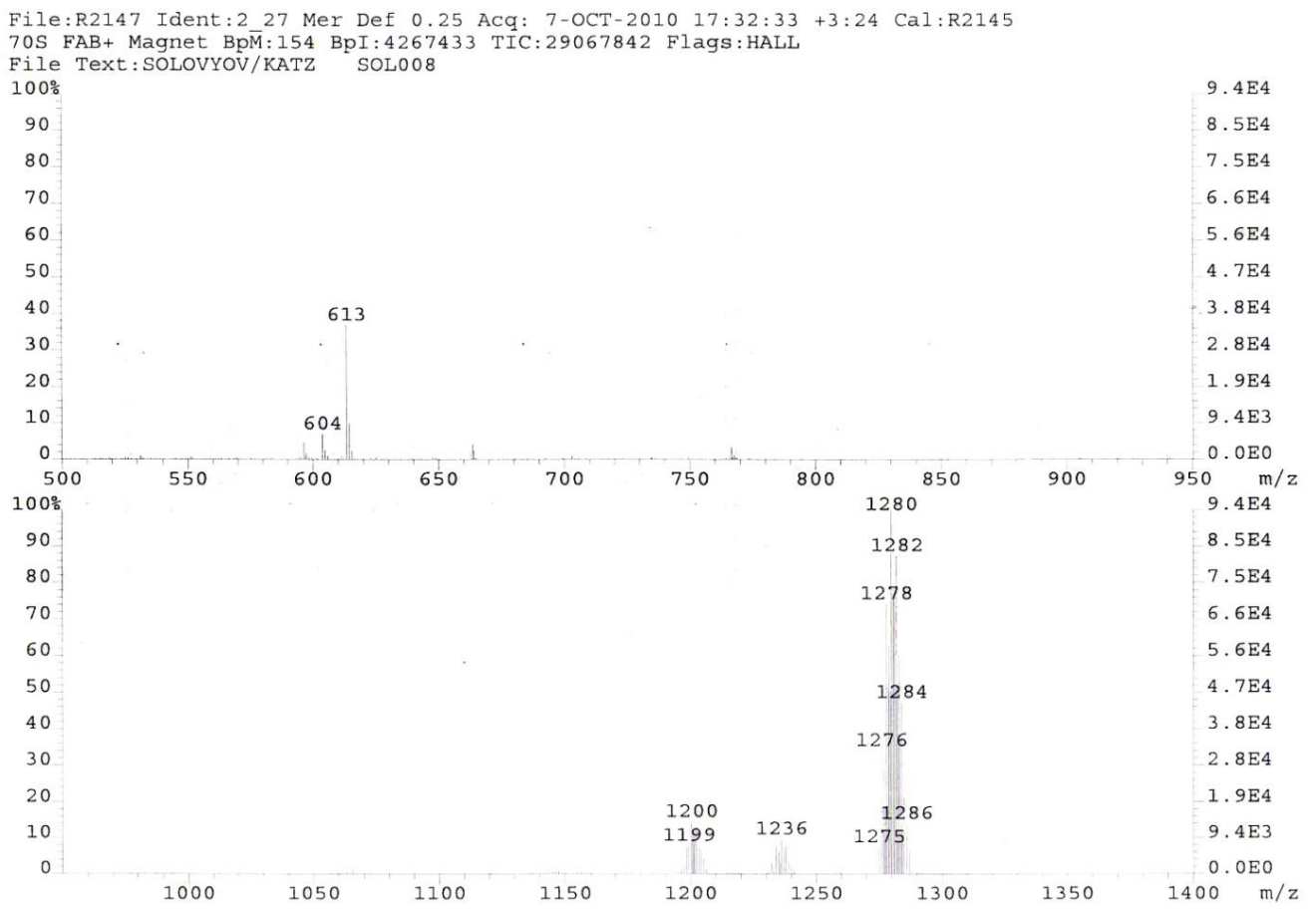

Figure 9: FAB MS of octabromo-calix[4]arene 2 
AVQ-400 QNP Proton starting parameters. 7/16/03. Revised 7/22/03 RH

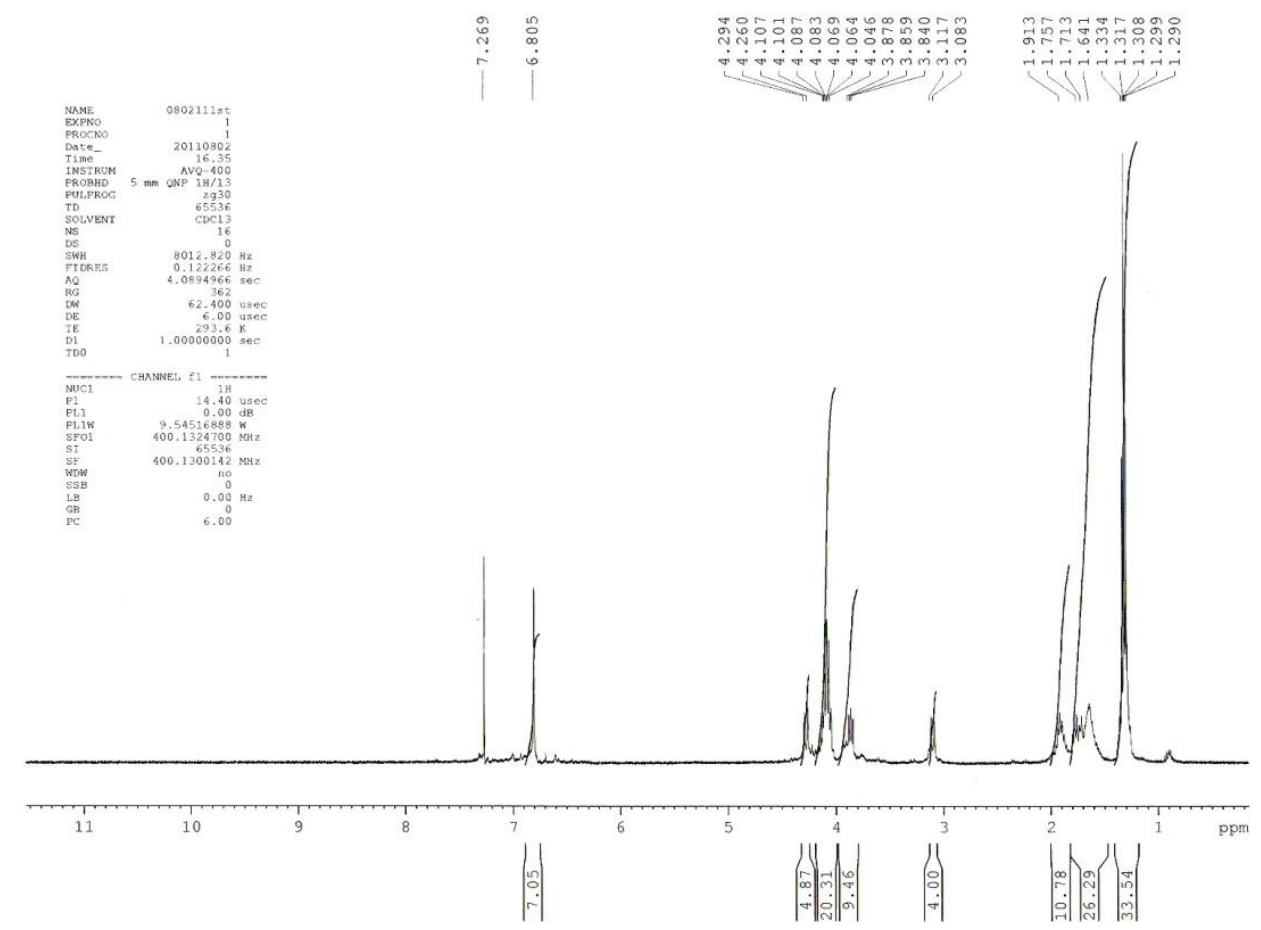

Figure 10: ${ }^{1} \mathrm{H}$ NMR spectrum of tetrabromo-calix[4]arene-tetraphosphonate 3

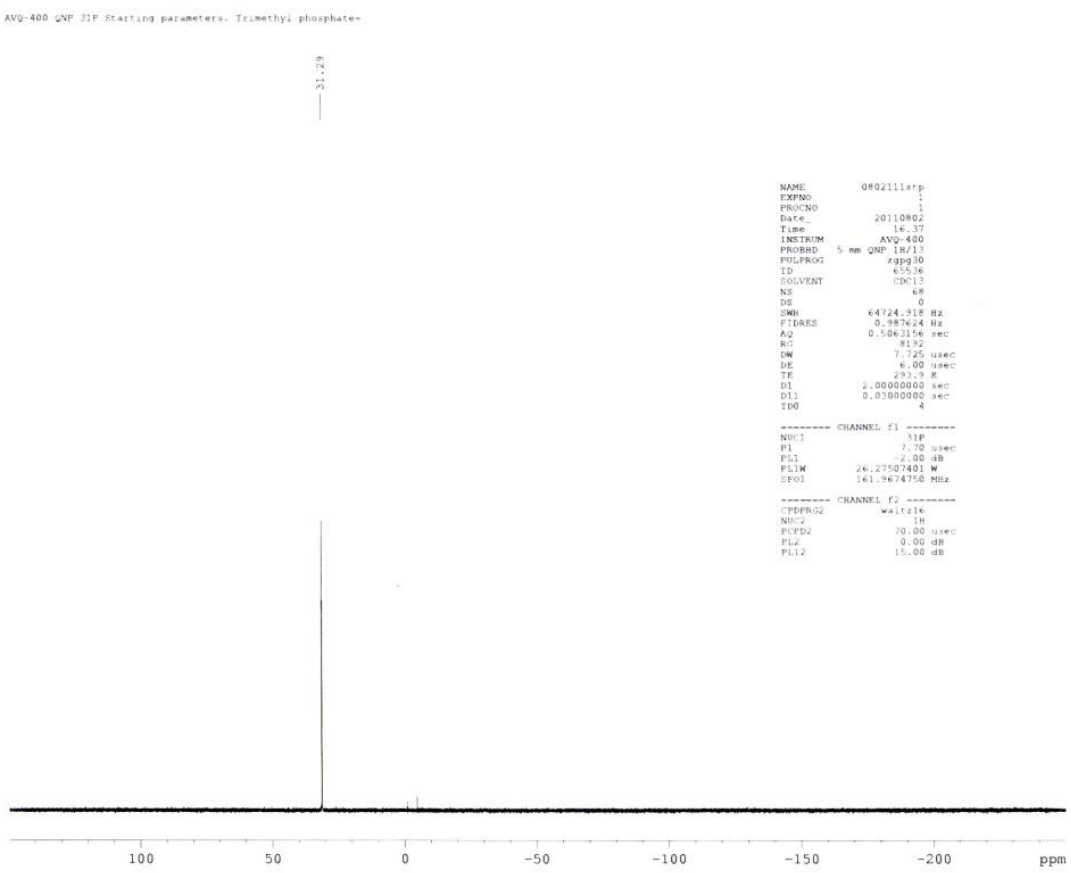

Figure 11: ${ }^{31} \mathrm{P}$ NMR spectrum of tetrabromo-calix[4]arene-tetraphosphonate 3 


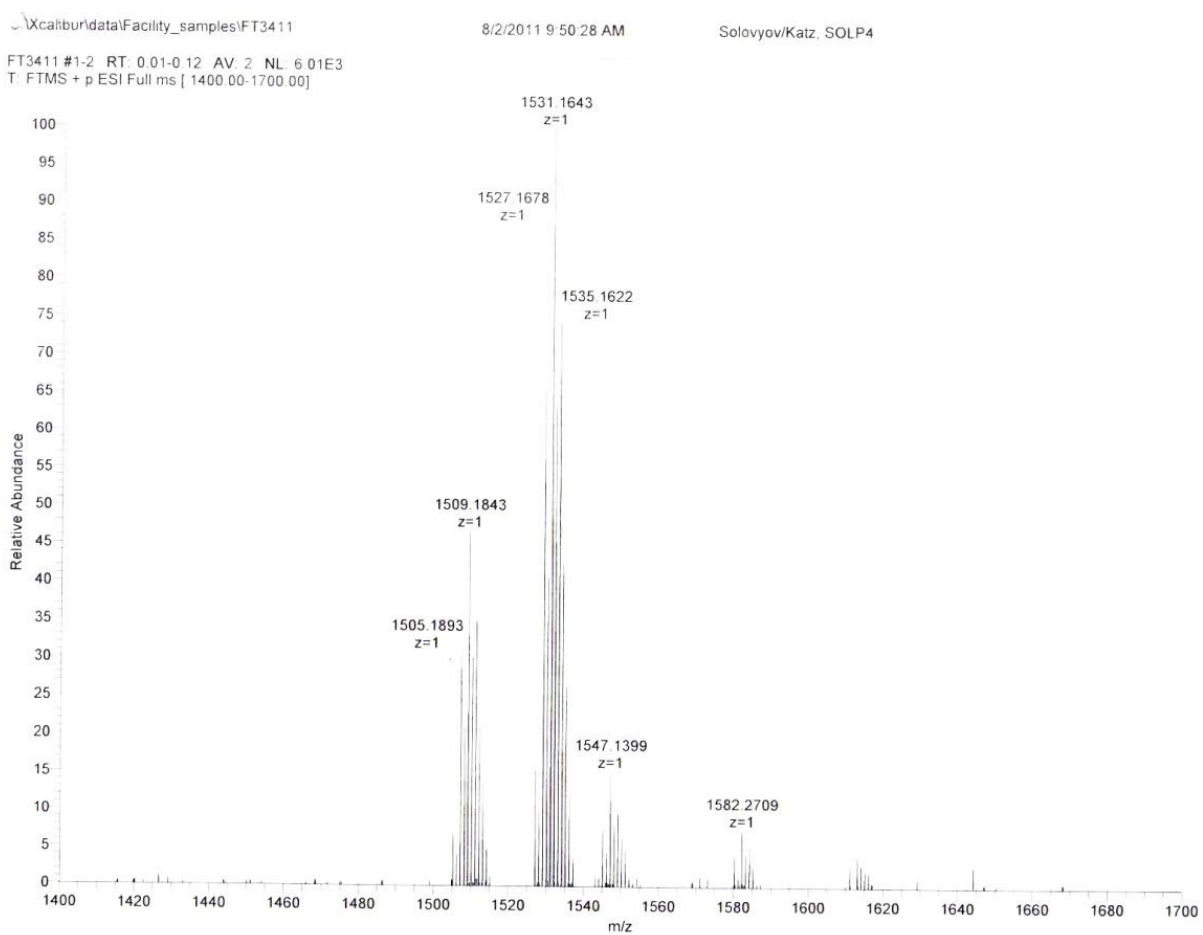

Figure 12: ESI MS spectrum of tetrabromo-calix[4]arene-tetraphosphonate 3

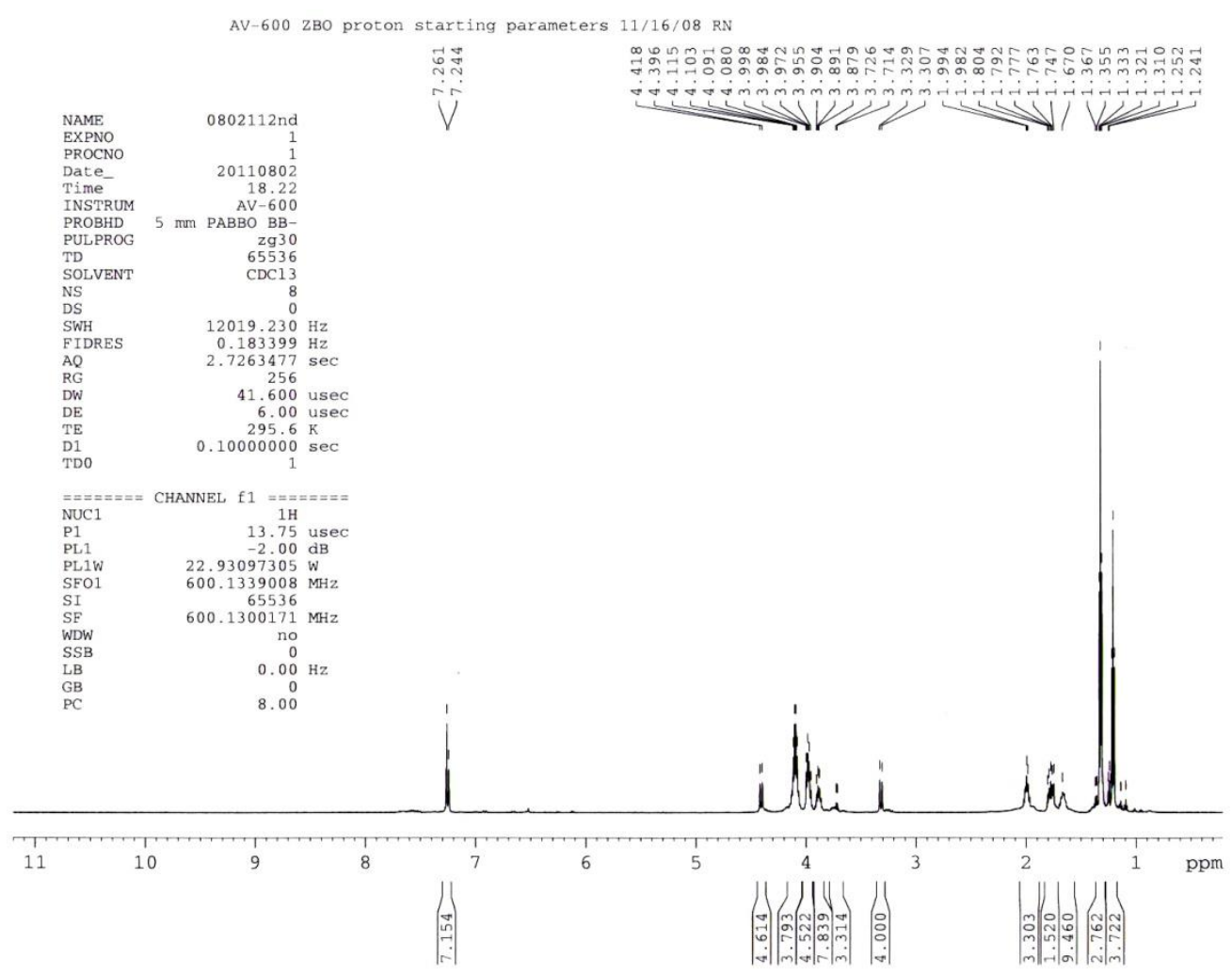

Figure 13: ${ }^{1} \mathrm{H}$ NMR spectrum of calix[4]arene-octaphosphonate 4 


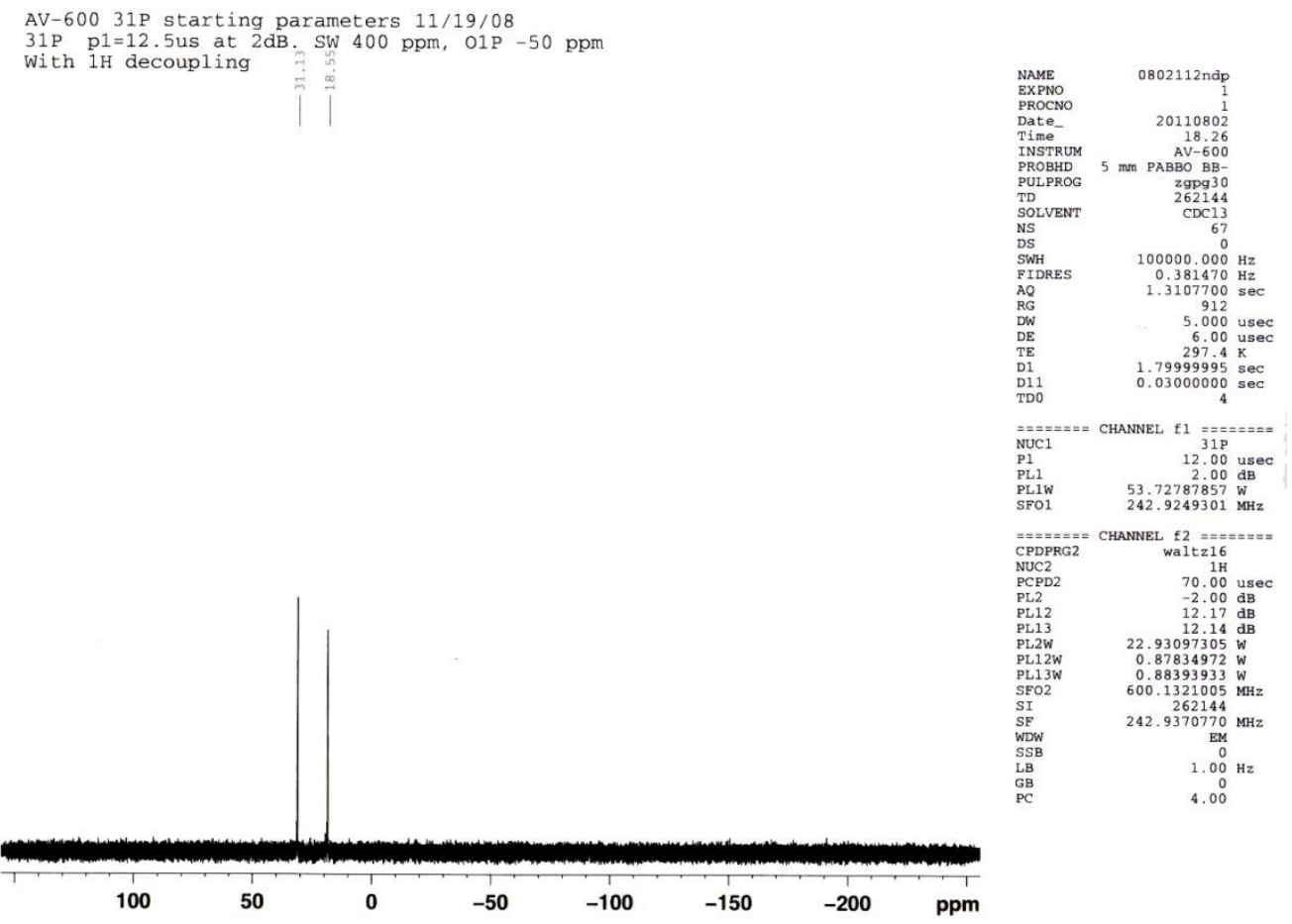

Figure 14: ${ }^{31} \mathrm{P}$ NMR spectrum of calix[4]arene-octaphosphonate 4

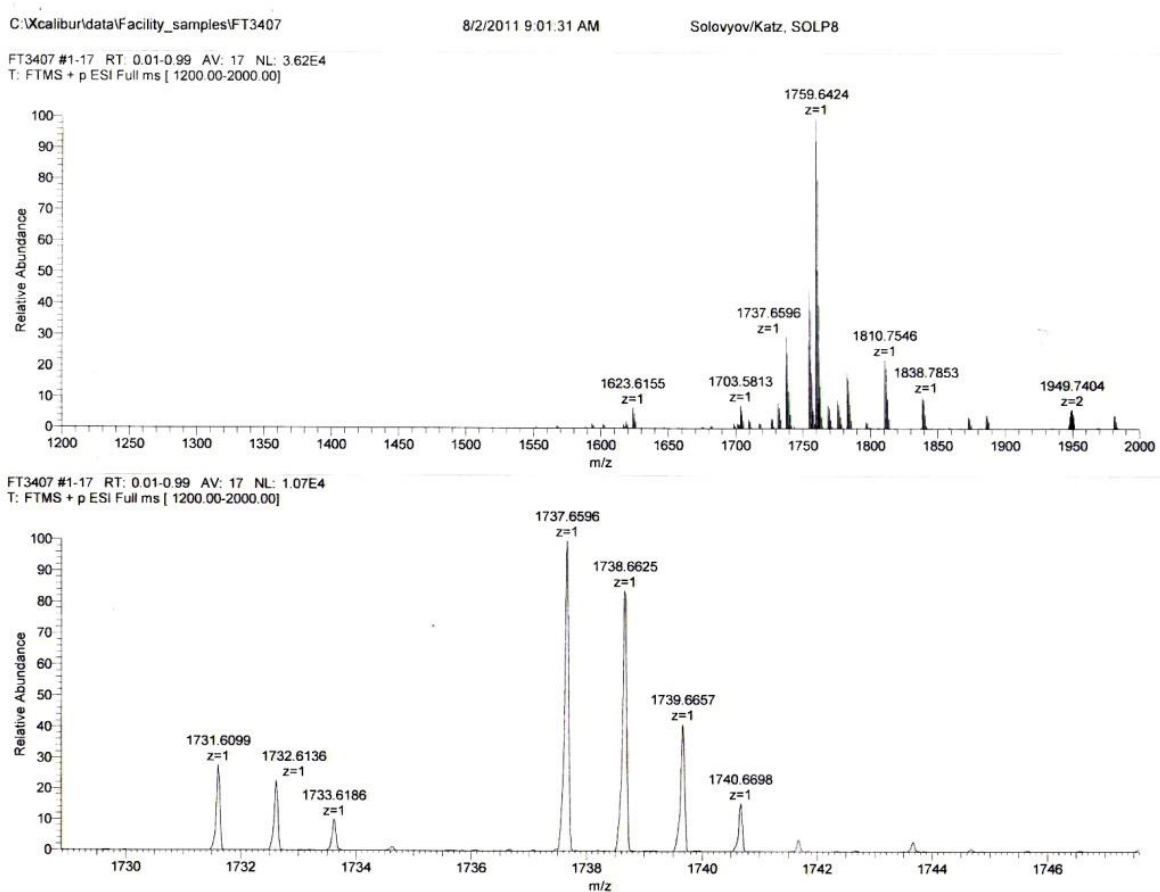

Figure 15: ESI MS spectrum of calix[4]arene-octaphosphonate 4 


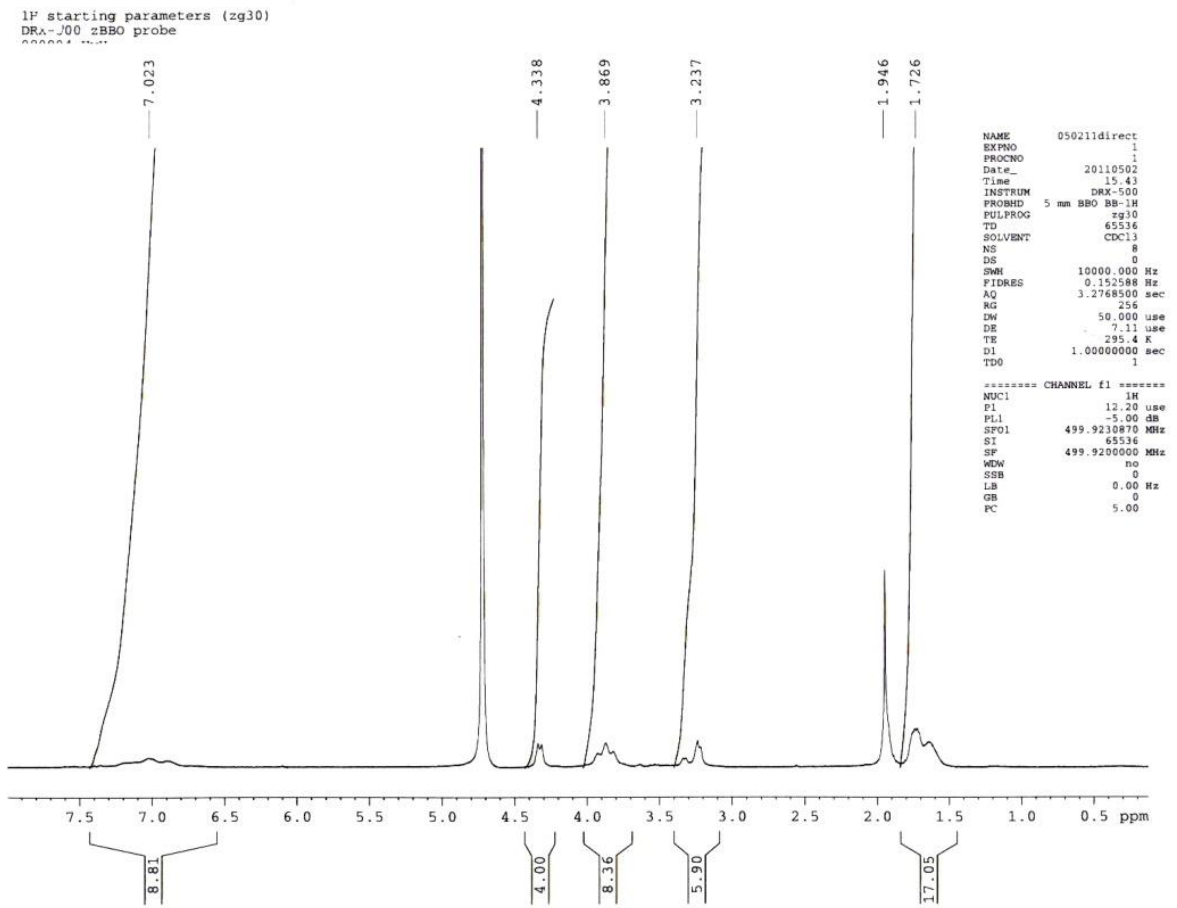

Figure 16: ${ }^{1} \mathrm{H}$ NMR spectrum of calix[4]arene-octaphosphonic acid 5

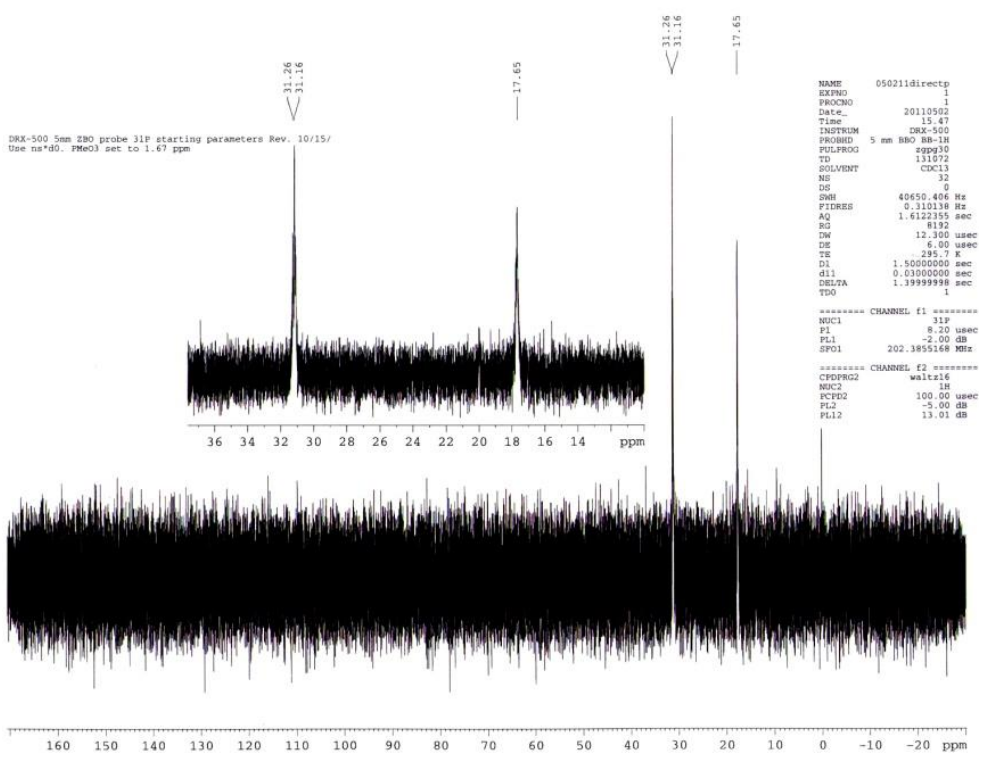

Figure 17: ${ }^{31} \mathrm{P}$ NMR spectrum of calix[4]arene-octaphosphonic acid 5 


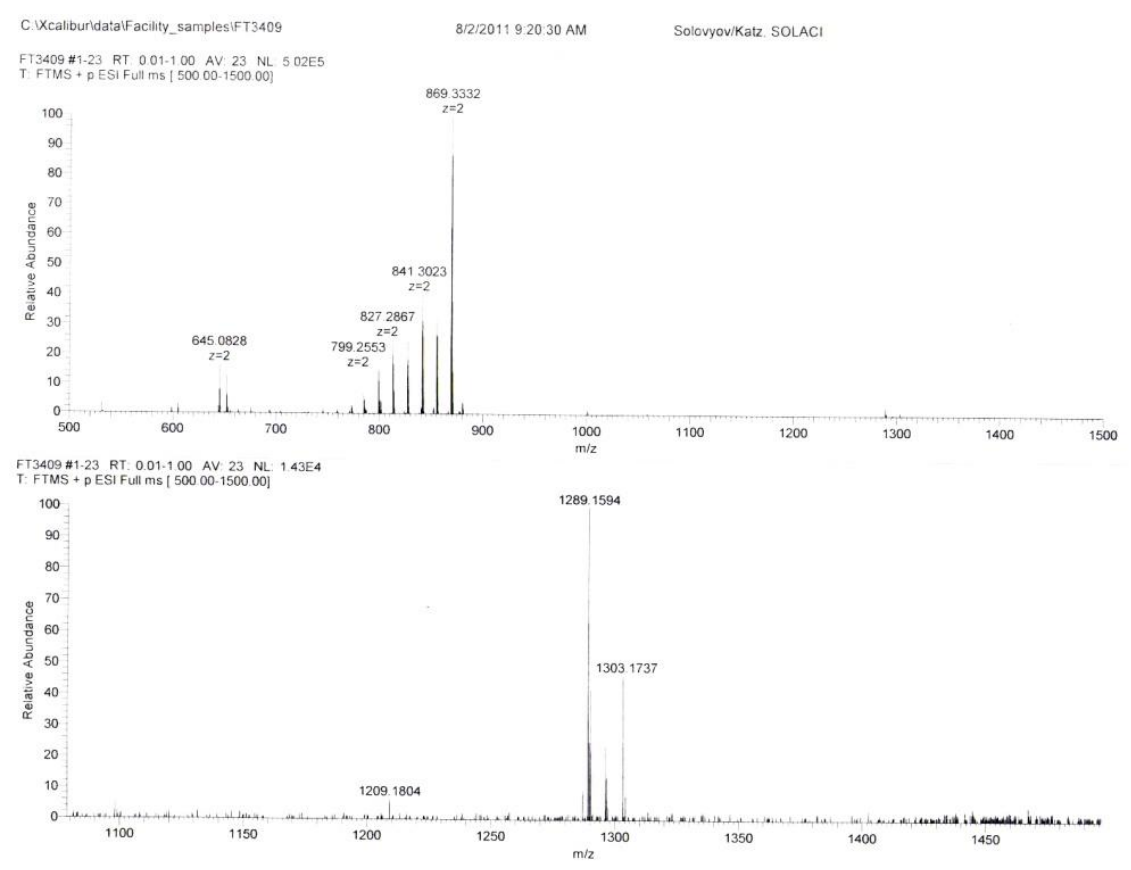

Figure 18: ESI MS spectrum of calix[4]arene octaphosphonic acid 5 
I) Base probe chemisorption on dispersed $\mathrm{C} 3 / \mathrm{SiO}_{2}$ and $\mathrm{C} 4 / \mathrm{SiO}$, Calixarene $/ \mathrm{SiO}_{2}$

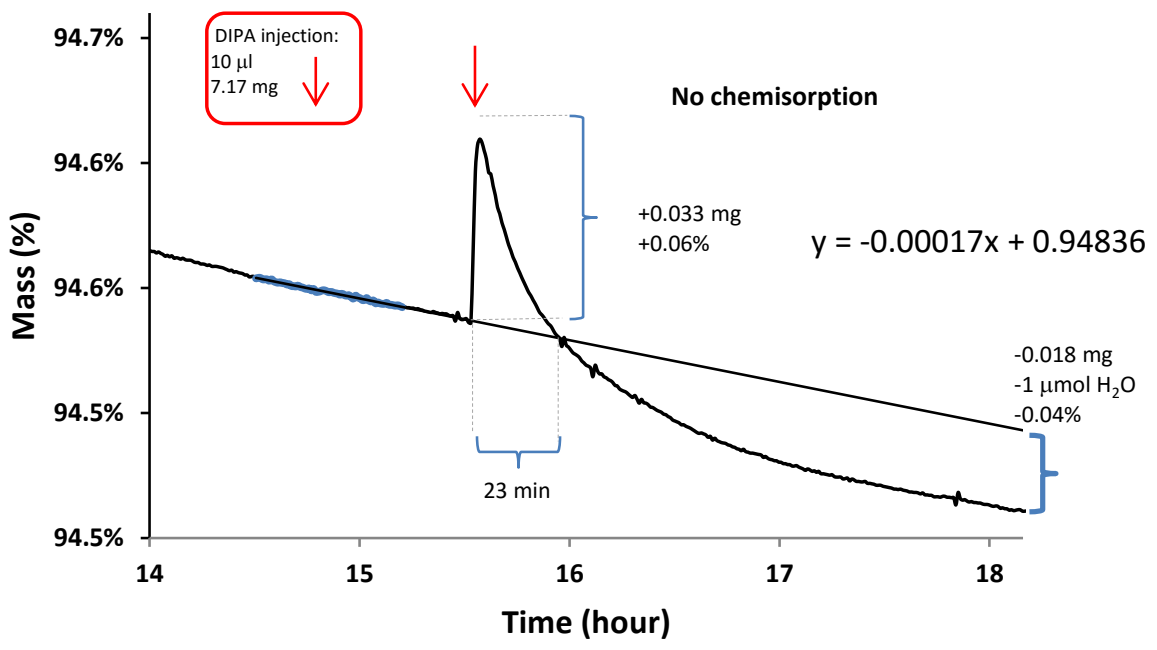

Figure 19: TGA isotherm analysis of DIPA adsorption on Selecto silica at $200^{\circ} \mathrm{C}$ (t4). The arrow correspond to the time of base probe injection.

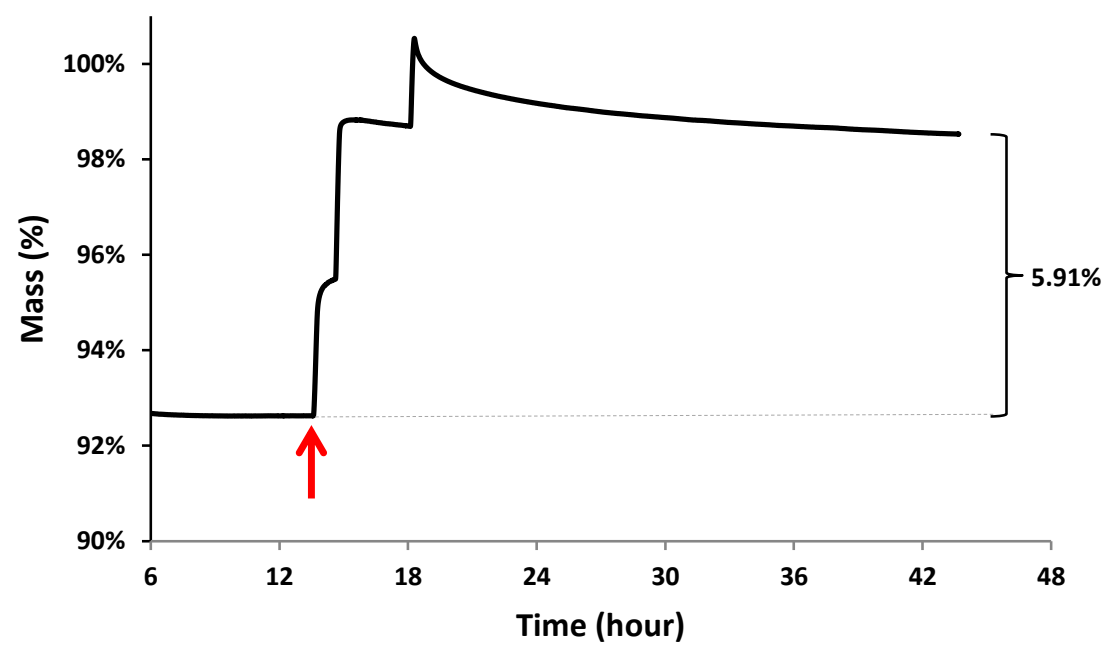

Figure 20: TGA isotherm analysis of DIPA adsorption on $\mathrm{C} 3 / \mathrm{SiO}_{2}-\mathbf{2 3} \%$ at $150^{\circ} \mathrm{C}$ (t9). The arrow correspond to the time of base probe injection. 


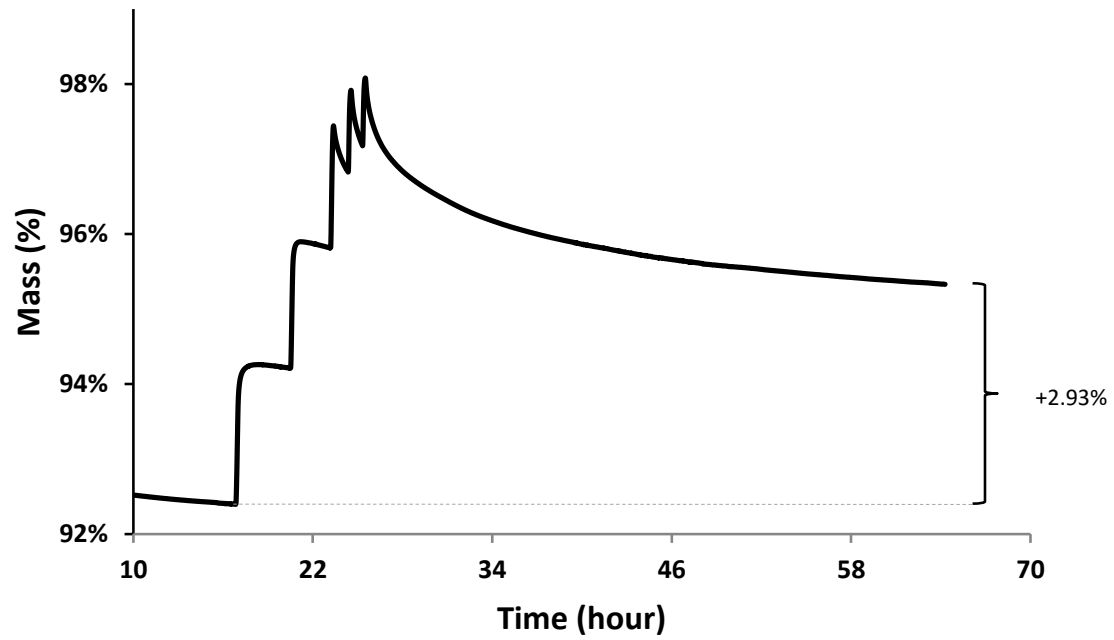

Figure 21: TGA isotherm analysis of DIPA adsorption on $\mathbf{C 3} / \mathrm{SiO}_{2}-\mathbf{2 3} \%$ at $200^{\circ} \mathrm{C}$ (t5). The arrow correspond to the time of base probe injection.

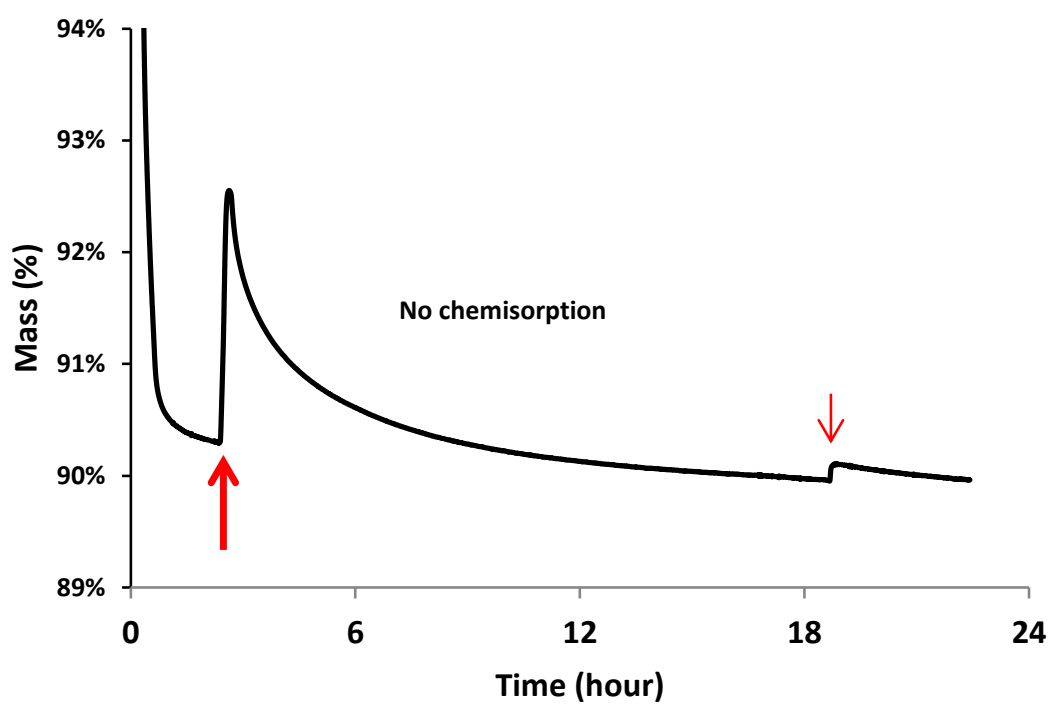

Figure 22: TGA isotherm analysis of DIPA adsorption on $\mathbf{C 3} / \mathrm{SiO}_{2}-\mathbf{2 3} \%$ at $300^{\circ} \mathrm{C}$ (t6). The arrow correspond to the time of base probe injection. 


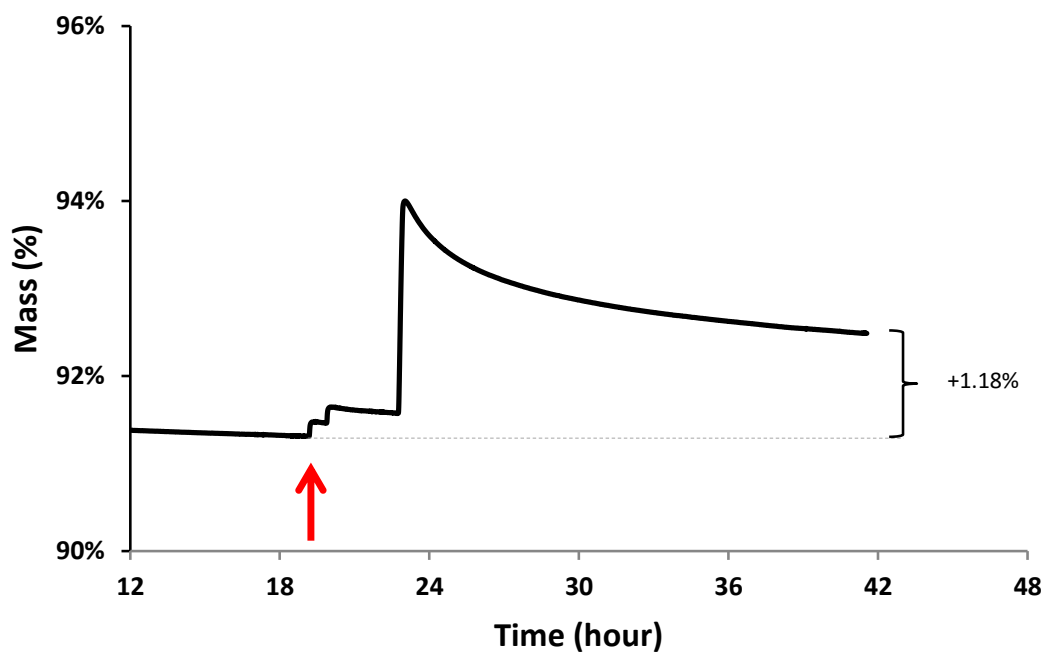

Figure 23: TGA isotherm analysis of DIPA adsorption on $\mathbf{C 3} / \mathrm{SiO}_{2}-\mathbf{2 3} \%$ at $250^{\circ} \mathrm{C}$ (t7). The arrow correspond to the time of base probe injection.

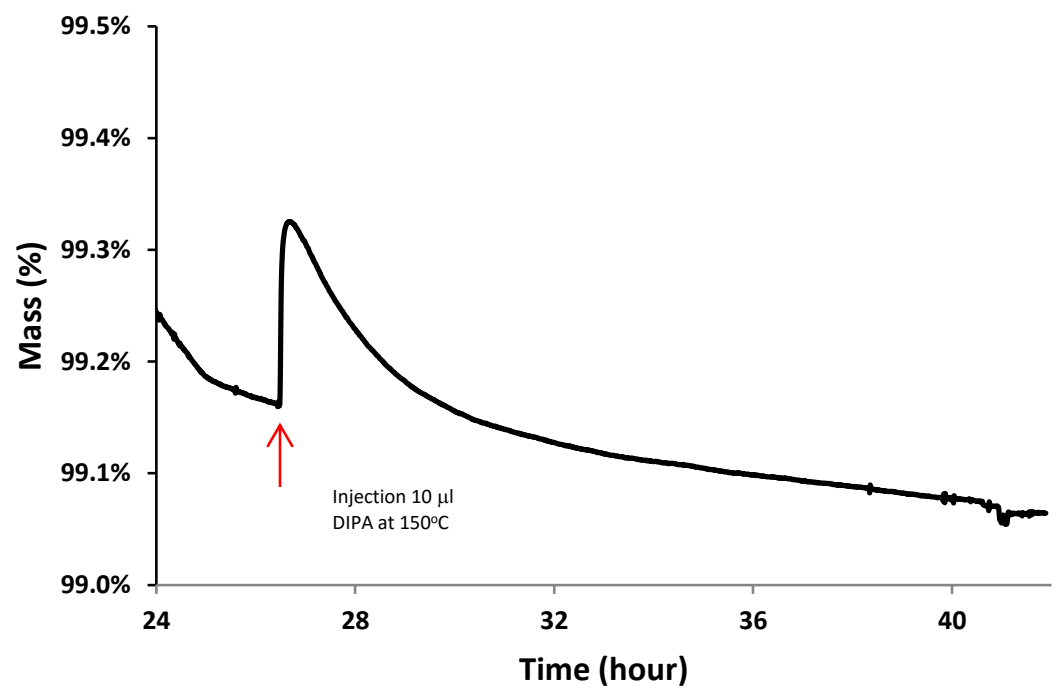

Figure 24: TGA isotherm analysis of DIPA adsorption on selecto silica at $150^{\circ} \mathrm{C}$ (t8). The arrow correspond to the time of base probe injection. 


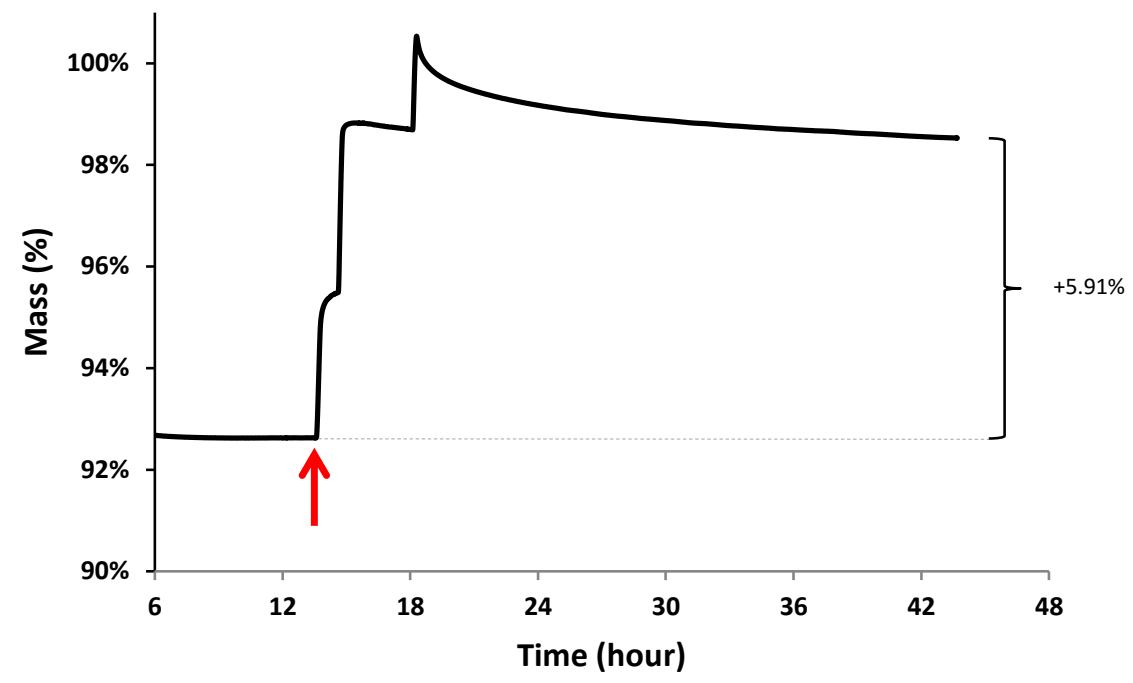

Figure 25: TGA isotherm analysis of DIPA adsorption on $\mathrm{C} 3 / \mathrm{SiO}_{2}-\mathbf{2 3} \%$ at $150^{\circ} \mathrm{C}$ (t9). The arrow correspond to the time of base probe injection.

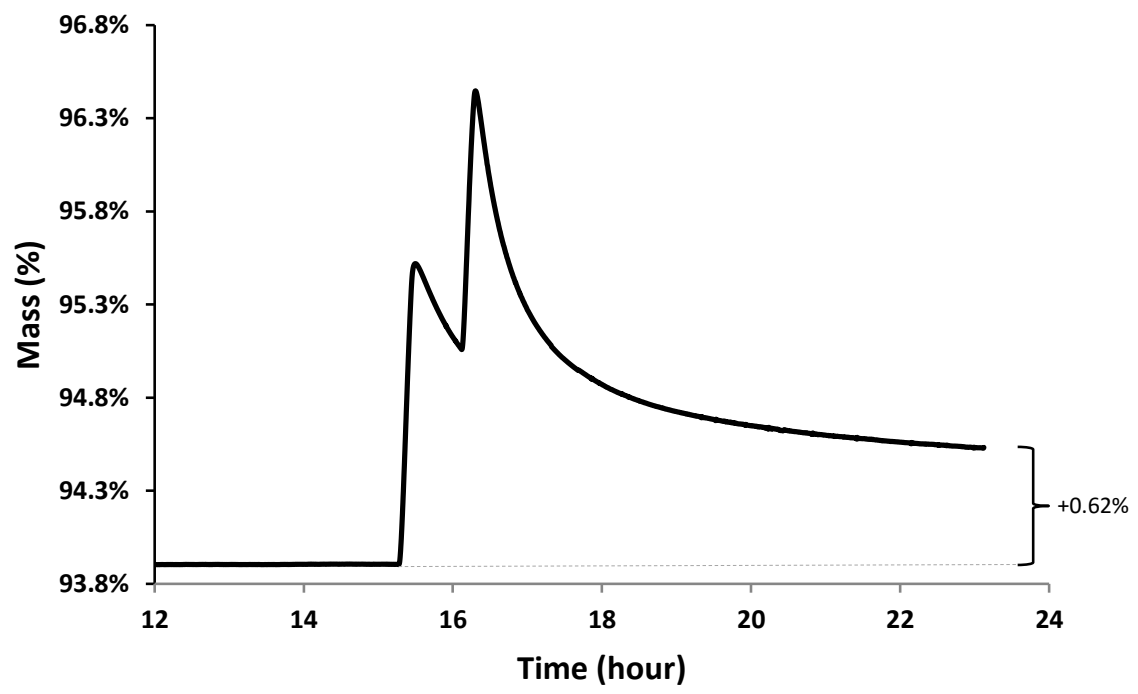

Figure 26: TGA isotherm analysis of DIPA adsorption on $\mathrm{C} 3 / \mathrm{SiO}_{2}-3 \%$ at $150^{\circ} \mathrm{C}$ (t10). The arrow correspond to the time of base probe injection. 


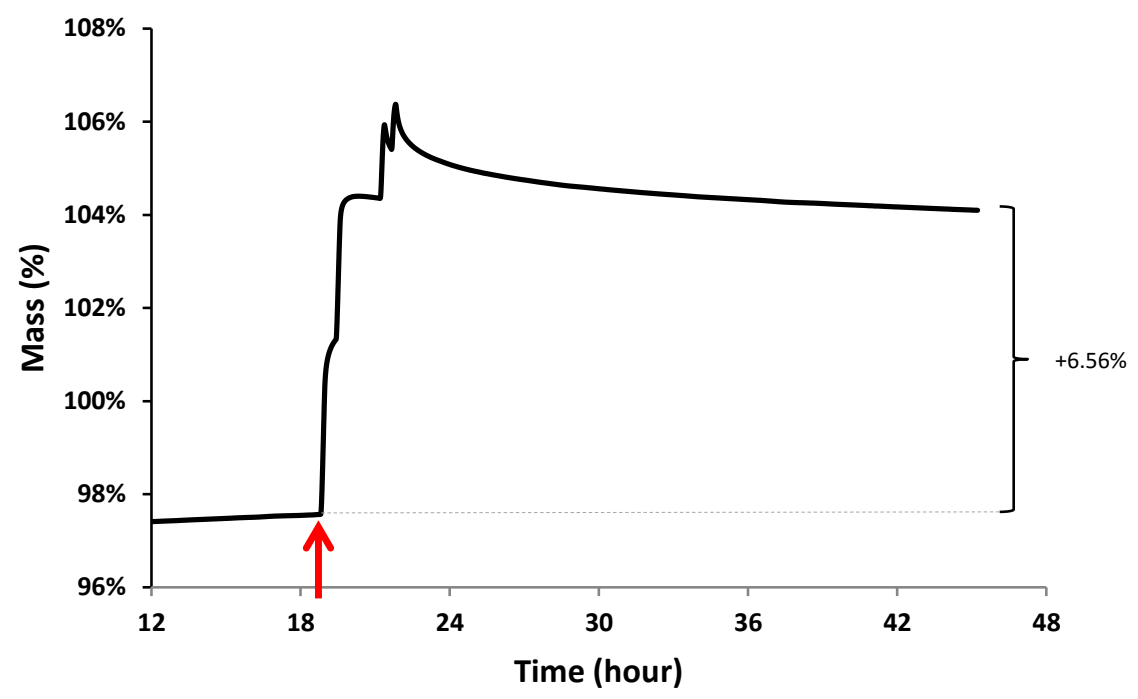

Figure 27: TGA isotherm analysis of DIPA adsorption on $\mathbf{C 4} / \mathrm{SiO}_{2}-\mathbf{2 3} \%$ at $150^{\circ} \mathrm{C}$ (t11). The arrow correspond to the time of base probe injection.

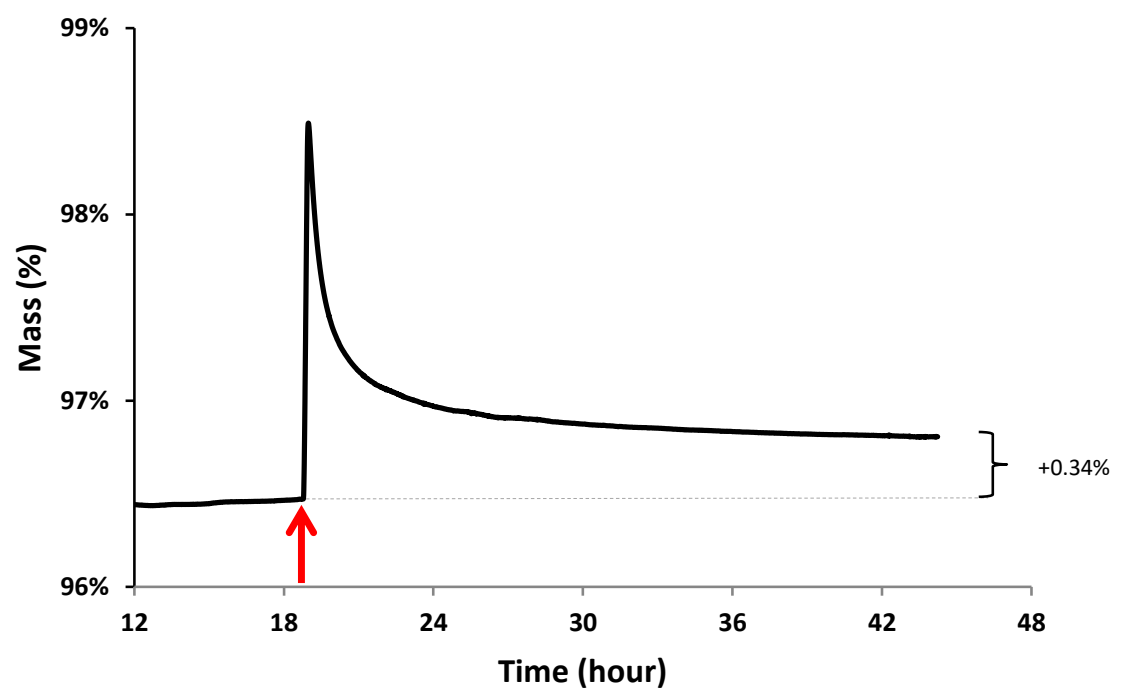

Figure 28: TGA isotherm analysis of DIPA adsorption on $\mathrm{C} 4 / \mathrm{SiO}_{2}-3 \%$ at $150^{\circ} \mathrm{C}$ (t12). The arrow correspond to the time of base probe injection. 


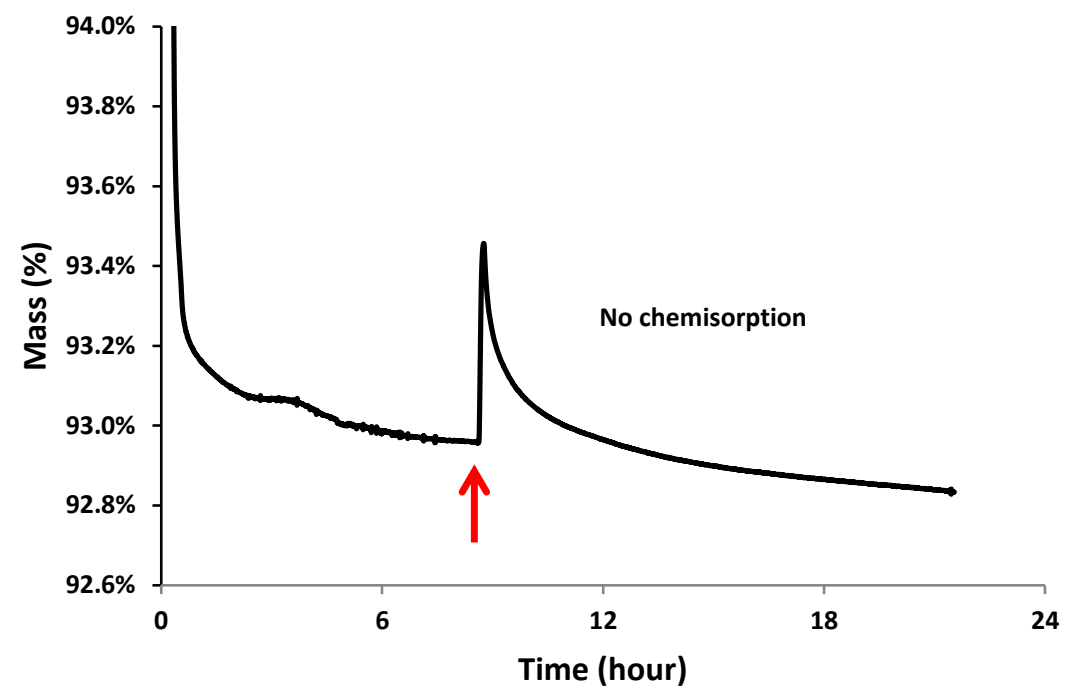

Figure 29: TGA isotherm analysis of DIPA adsorption on $\mathbf{C} 3 / \mathrm{SiO}_{2}-3 \%$ at $250^{\circ} \mathrm{C}$

(t13). The arrow correspond to the time of base probe injection.

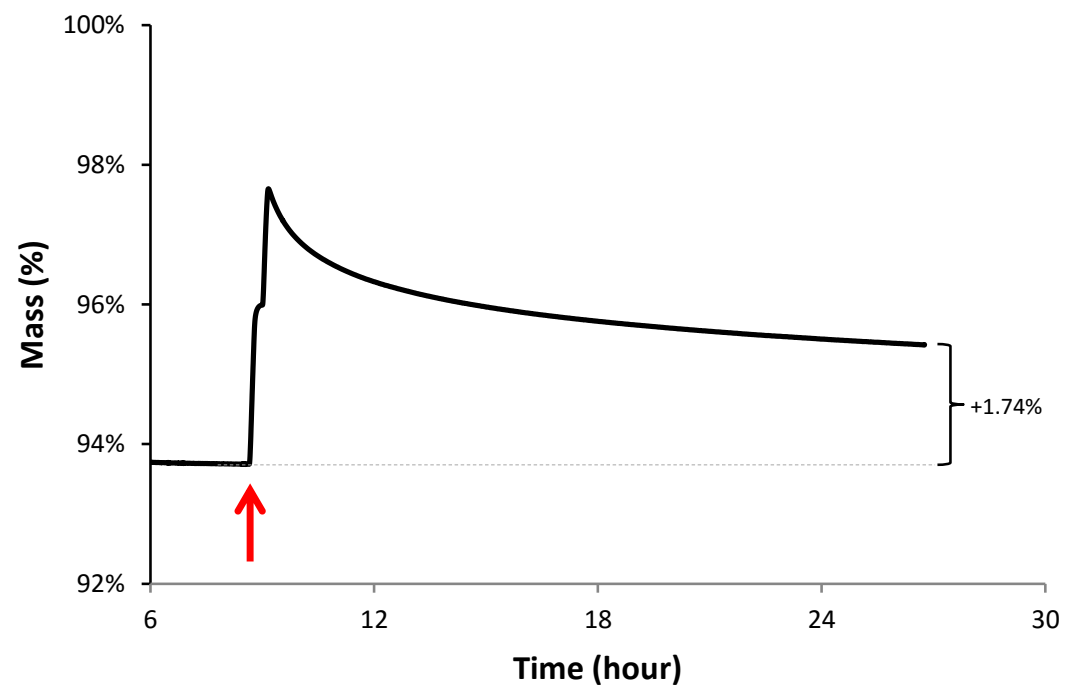

Figure 30: TGA isotherm analysis of DIPA adsorption on $\mathbf{C 4} / \mathrm{SiO}_{2}-\mathbf{2 3} \%$ at $250^{\circ} \mathrm{C}$ (t14). The arrow correspond to the time of base probe injection. 


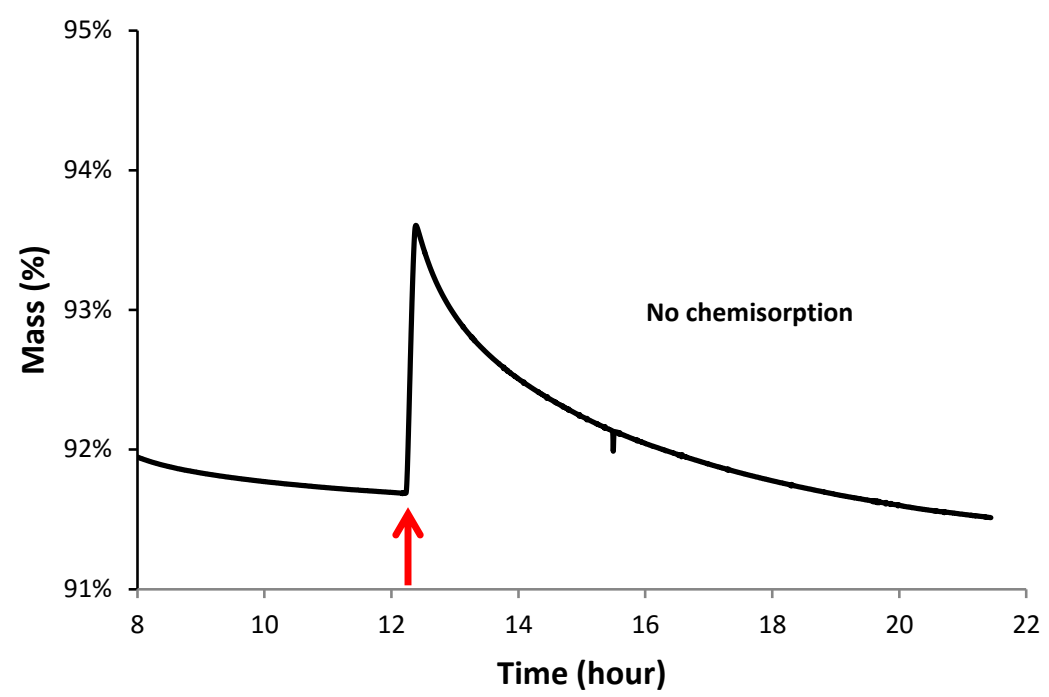

Figure 31: TGA isotherm analysis of DIPA adsorption on $\mathbf{C 4} / \mathrm{SiO}_{2}-\mathbf{2 3} \%$ at $300^{\circ} \mathrm{C}$ (t15). The arrow correspond to the time of base probe injection.

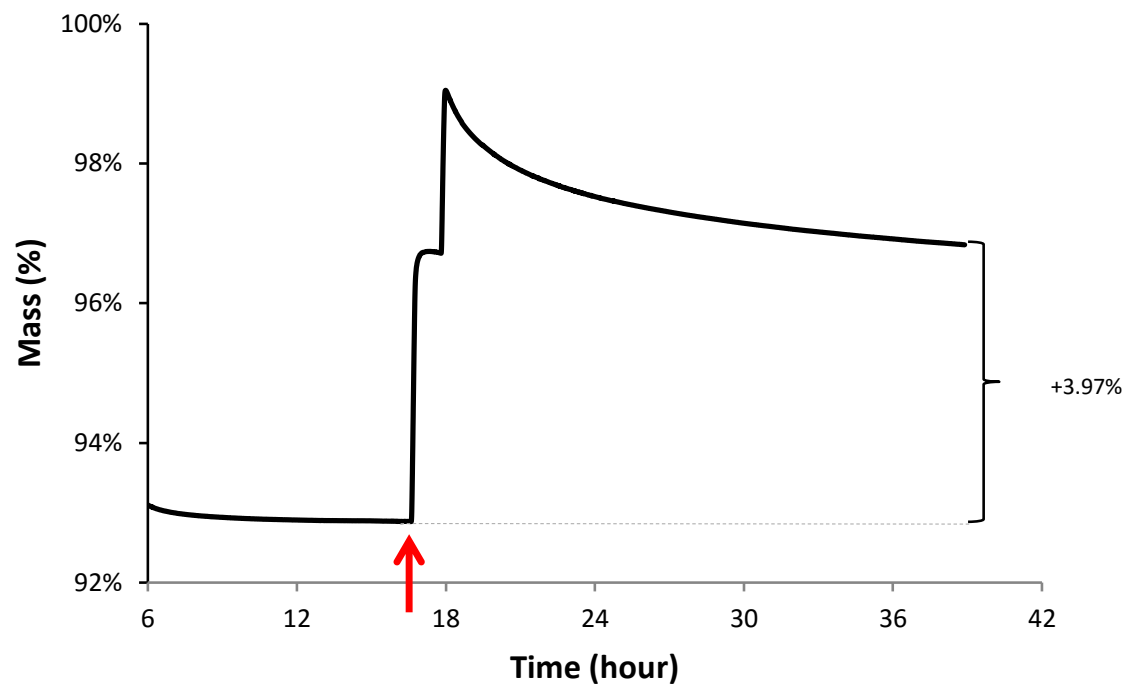

Figure 32: TGA isotherm analysis of DIPA adsorption on $\mathrm{C} 4 / \mathrm{SiO}_{2}-\mathbf{2 3} \%$ at $200^{\circ} \mathrm{C}$ (t16). The arrow correspond to the time of base probe injection. 


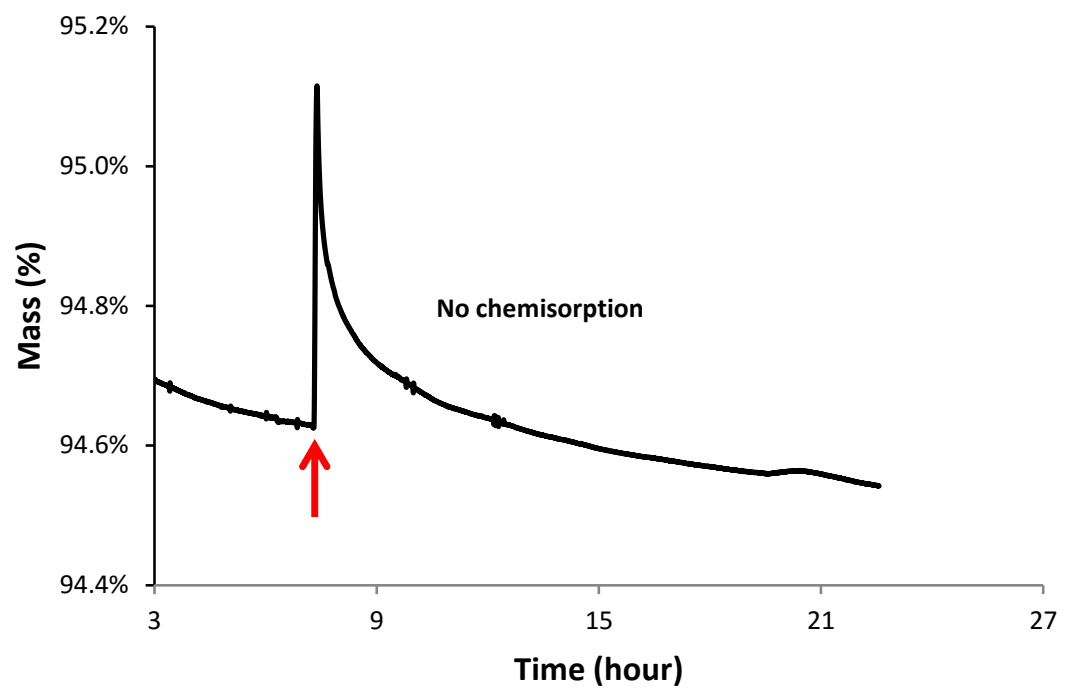

Figure 33: TGA isotherm analysis of DIPA adsorption on $\mathrm{C} 4 / \mathrm{SiO}_{2}-3 \%$ at $250^{\circ} \mathrm{C}$ (t17). The arrow correspond to the time of base probe injection.

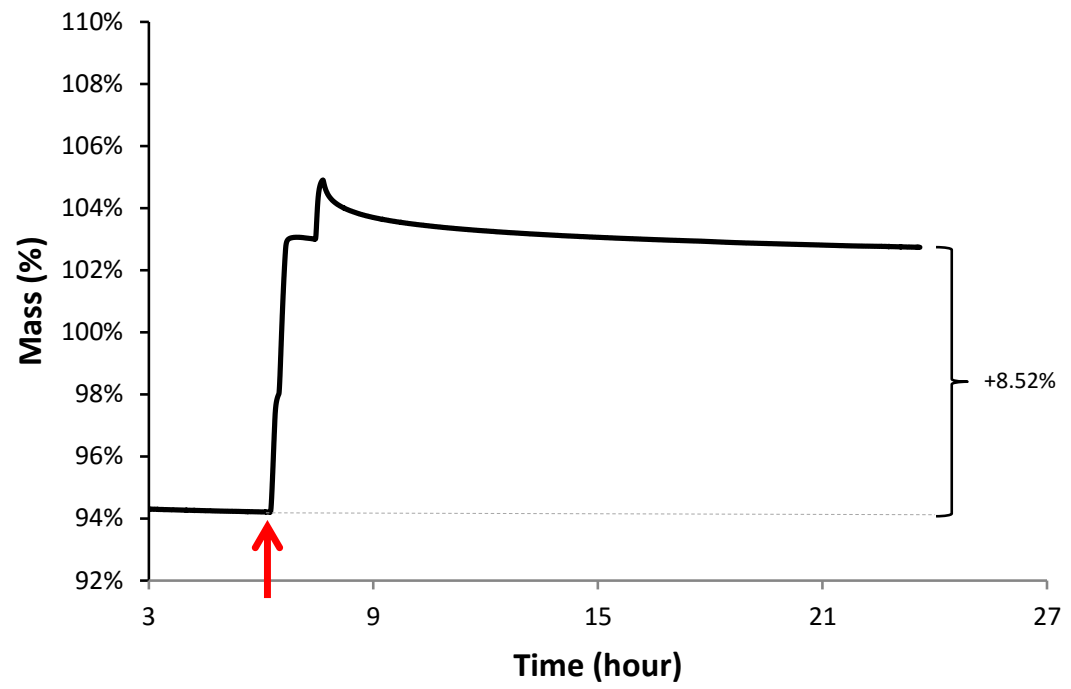

Figure 34: TGA isotherm analysis of DIPA adsorption on $\mathbf{C 4} / \mathrm{SiO}_{2}-\mathbf{3 7} \%$ at $150^{\circ} \mathrm{C}$ (t18). The arrow correspond to the time of base probe injection. 


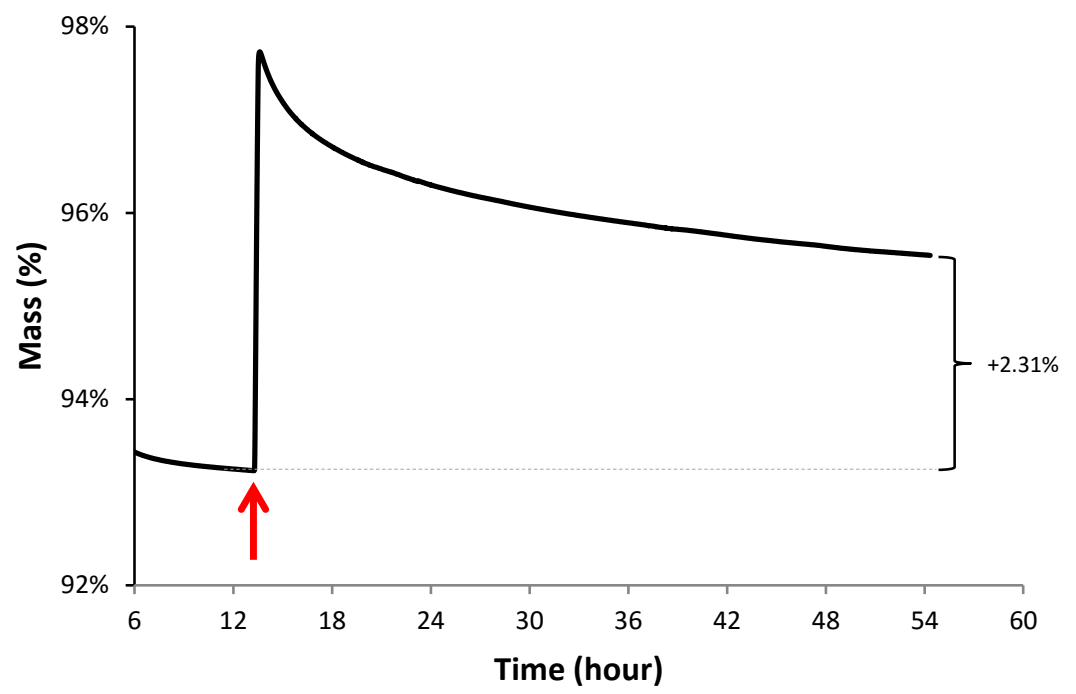

Figure 35: TGA isotherm analysis of DIPA adsorption on $\mathbf{C 4} / \mathrm{SiO}_{2}-\mathbf{3 7 \%}$ at $250^{\circ} \mathrm{C}$ (t19). The arrow correspond to the time of base probe injection.

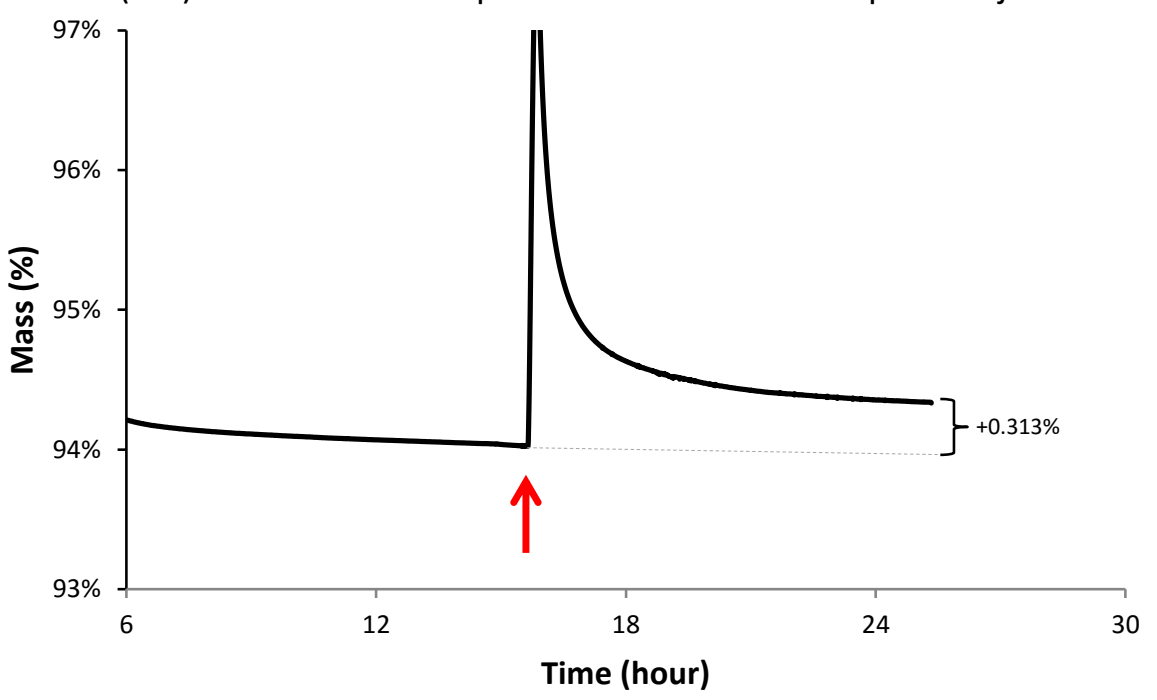

Figure 36: TGA isotherm analysis of DIPA adsorption on $\mathrm{CX8} / \mathrm{SiO}_{2}-5 \%$ at $150^{\circ} \mathrm{C}$ (t20). The arrow correspond to the time of base probe injection. 


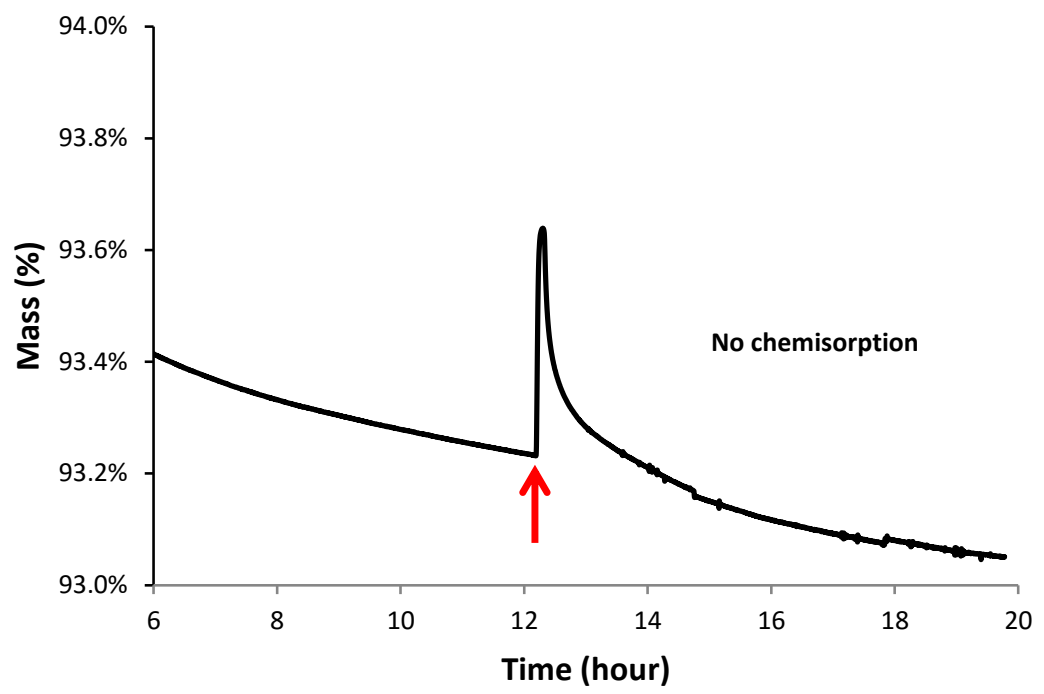

Figure 37: TGA isotherm analysis of DIPA adsorption on $\mathbf{C X 8} / \mathrm{SiO}_{2}-5 \%$ at $250^{\circ} \mathrm{C}$ (t21). The arrow correspond to the time of base probe injection.

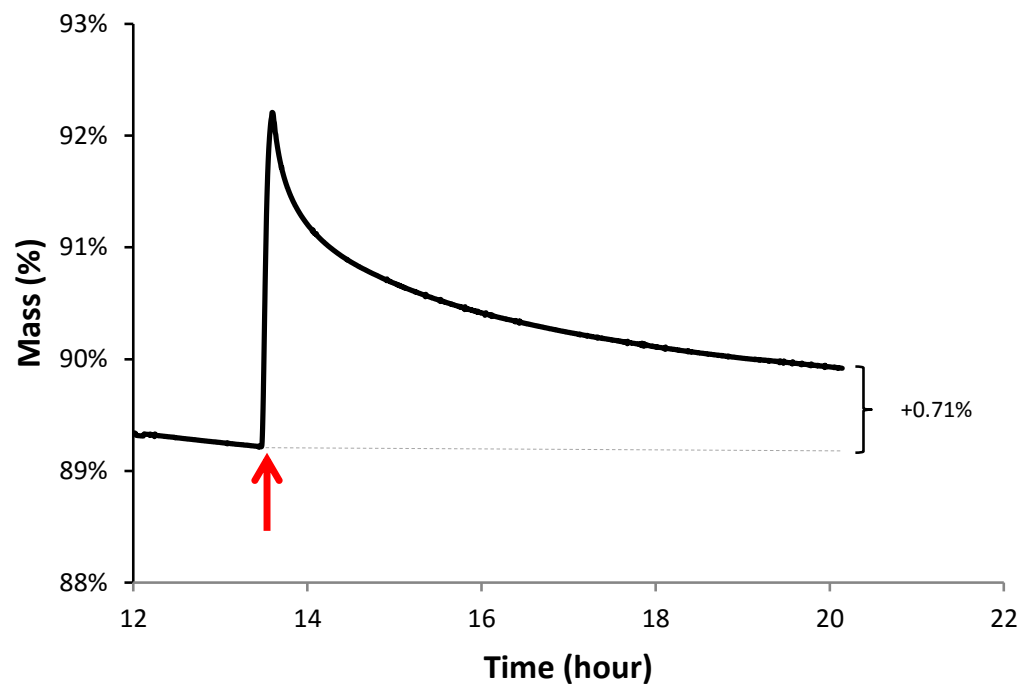

Figure 38: TGA isotherm analysis of DIPA adsorption on $\mathrm{CX8} / \mathrm{SiO}_{2}-35 \%$ at $250^{\circ} \mathrm{C}$ (t24). The arrow correspond to the time of base probe injection. 


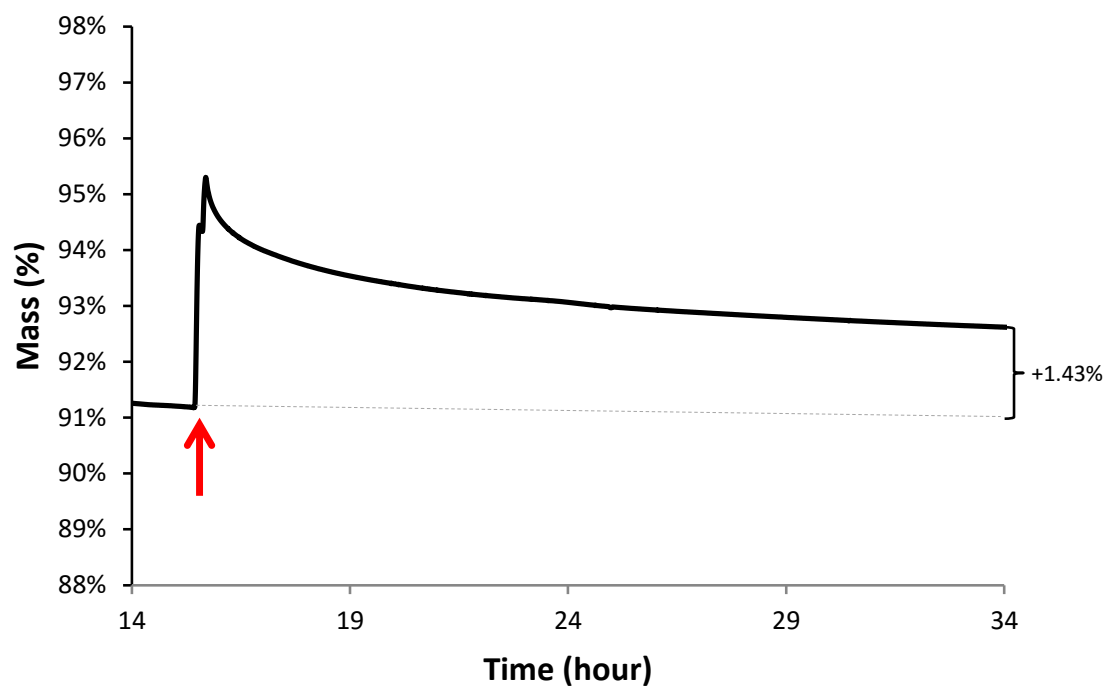

Figure 39: TGA isotherm analysis of DIPA adsorption on $\mathrm{CX8} / \mathrm{SiO}_{2}-35 \%$ at $200^{\circ} \mathrm{C}$ (t25). The arrow correspond to the time of base probe injection.

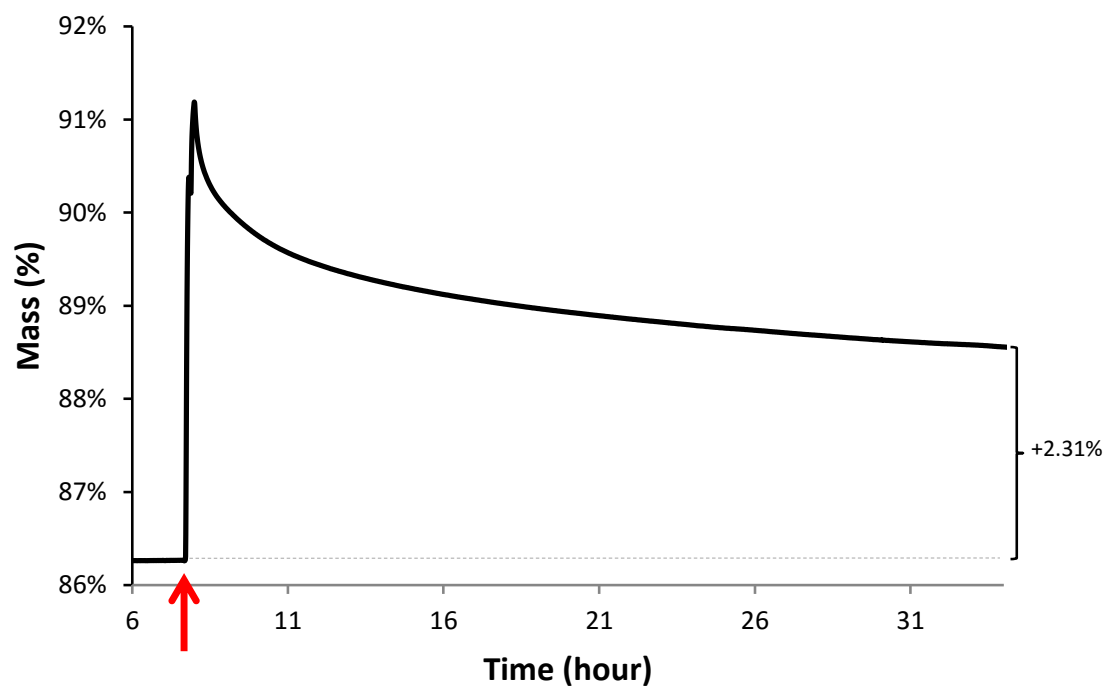

Figure 40: TGA isotherm analysis of DIPA adsorption on $\mathbf{C 4} / \mathrm{SiO}_{2}-54 \%$ at $250^{\circ} \mathrm{C}$ (t26). The arrow correspond to the time of base probe injection. 


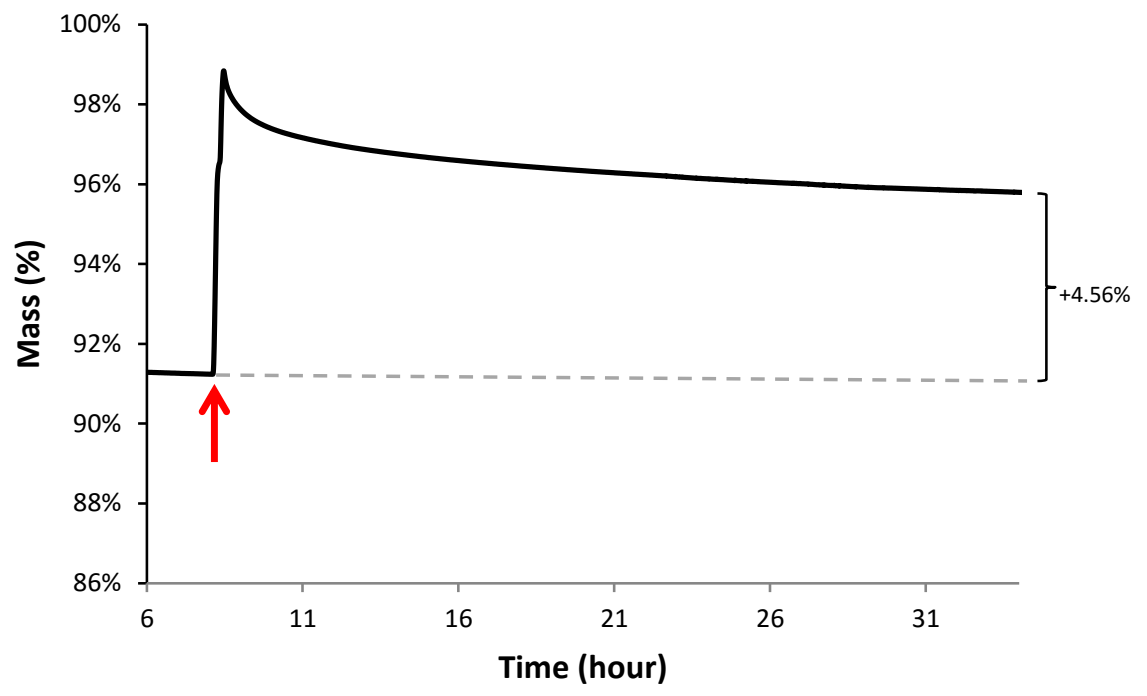

Figure 41: TGA isotherm analysis of DIPA adsorption on PVPA $/ \mathrm{SiO}_{2}-40 \%$ at $150^{\circ} \mathrm{C}$ (coverage aprox. 100\%). The arrow correspond to the time of base probe injection. 
C3: X-ray quality crystals were grown by sublimation at room temperature and at atmospheric pressure over a period of one month. A colorless prism $0.12 \times 0.10 \times 0.10 \mathrm{~mm}$ in size was mounted on a Cryoloop with Paratone oil. Data were collected in a nitrogen gas stream at 100(2) K using phi and omega scans. Crystal-to-detector distance was $60 \mathrm{~mm}$ and exposure time was 5 seconds per frame using a scan width of $1.0^{\circ}$. Data collection was $97.3 \%$ complete to $67.00^{\circ}$ in $\theta$. A total of 8289 reflections were collected covering the indices, $-6<=h<=6,-9<=k<=8,-13<=l<=13$. 1734 reflections were found to be symmetry independent, with an $\mathrm{R}_{\text {int }}$ of 0.0107 . Indexing and unit cell refinement indicated a primitive, triclinic lattice. The space group was found to be P-1 (No. 2).

C4: A colorless prism $0.080 \times 0.070 \times 0.060 \mathrm{~mm}$ in size was mounted on a Cryoloop with Paratone oil. Data were collected in a nitrogen gas stream at 100(2) K using phi and omega scans. Crystal-to-detector distance was $60 \mathrm{~mm}$ and exposure time was 5 seconds per frame using a scan width of $1.0^{\circ}$. Data collection was $99.7 \%$ complete to $67.000^{\circ}$ in $\theta$. A total of 19051 reflections were collected covering the indices, $18<=h<=18,-6<=k<=6,-16<=l<=17.2094$ reflections were found to be symmetry independent, with an $\mathrm{R}_{\text {int }}$ of 0.0228 . Indexing and unit cell refinement indicated a $\mathrm{C}$-centered, monoclinic lattice. The space group was found to be C $2 / \mathrm{c}$ (No. 15).

The data were integrated using the Bruker SAINT software program and scaled using the SADABS software program. Solution by direct methods (SIR-2004 and SIR-2011) produced a complete heavy-atom phasing model consistent with the proposed structure. All non-hydrogen atoms were refined anisotropically by full-matrix least-squares (SHELXL-97 and SHELXL-2013). All hydrogen atoms were placed using a riding model. Their positions were constrained relative to their parent atom using the appropriate HFIX command in SHELXL-97 and SHELXL-2013.

Table 1: Crystal data and structure refinement.for $\mathrm{C3}$ and $\mathrm{C4}$

\begin{tabular}{|c|c|c|}
\hline & C3 crystal & C4 crystal \\
\hline Empirical formula & C3 H11 O9 P3 & C4 H14 O12 P4 \\
\hline Formula weight & 284.03 & 378.03 \\
\hline Temperature & $100 \mathrm{~K}$ & $100 \mathrm{~K}$ \\
\hline Wavelength & $1.54178 \AA$ & $1.54178 \AA$ \\
\hline Crystal system & Triclinic & Monoclinic \\
\hline Space group & $\mathrm{P}-1$ & $\mathrm{C} 2 / \mathrm{c}$ \\
\hline Unit cell dimensions & $\begin{array}{l}\mathrm{a}=5.6554(2) \AA, \quad \alpha=95.0050(10)^{\circ} \\
\mathrm{b}=8.2057(4) \AA, \quad \beta=102.7290(10)^{\circ} . \\
\mathrm{c}=11.6388(5) \AA, \quad \gamma= \\
108.4680(10)^{\circ} .\end{array}$ & $\begin{array}{l}\mathrm{a}=15.7769(13), \alpha=90^{\circ} . \\
\mathrm{b}=5.6515(4) \AA, \beta=101.306(3)^{\circ} . \\
\mathrm{c}=14.2338(11) \AA, \gamma=90^{\circ} .\end{array}$ \\
\hline & $\gamma=108.4680(10)^{\circ}$. & \\
\hline Volume & $492.46(4) \AA^{3}$ & $1244.50(17) \AA^{3}$ \\
\hline $\mathrm{Z}$ & 2 & 4 \\
\hline Density (calculated) & $1.915 \mathrm{Mg} / \mathrm{m}^{3}$ & $2.018 \mathrm{Mg} / \mathrm{m}^{3}$ \\
\hline Absorption coefficient & $5.951 \mathrm{~mm}^{-1}$ & $6.279 \mathrm{~mm}^{-1}$ \\
\hline $\mathrm{F}(000)$ & 292 & 776 \\
\hline Crystal size & $0.12 \times 0.10 \times 0.10 \mathrm{~mm}^{3}$ & $0.080 \times 0.070 \times 0.060 \mathrm{~mm}^{3}$ \\
\hline Crystal color/habit & colorless prism & colorless prism \\
\hline Theta range for data collection & 3.95 to $68.25^{\circ}$. & 5.719 to $68.236^{\circ}$. \\
\hline Index ranges & $-6<=\mathrm{h}<=6,-9<=\mathrm{k}<=8,-13<=\mathrm{l}<=13$ & $\begin{array}{l}-18<=\mathrm{h}<=18,-6<=\mathrm{k}<=6,- \\
16<=1<=17\end{array}$ \\
\hline Reflections collected & 8289 & 19051 \\
\hline Independent reflections & $1734[\mathrm{R}($ int $)=0.0107]$ & $2094[\mathrm{R}(\mathrm{int})=0.0228]$ \\
\hline
\end{tabular}


Completeness to theta $=67.00^{\circ} \quad 97.3 \%$

Absorption correction

Max. and min. transmission

Refinement method

Data / restraints / parameters

Goodness-of-fit on $\mathrm{F}^{2}$

Final $\mathrm{R}$ indices [I>2sigma(I)]

$\mathrm{R}$ indices (all data)

Largest diff. peak and hole
Semi-empirical from equivalents

0.5875 and 0.5353

Full-matrix least-squares on $\mathrm{F}^{2}$

1734 / 0 / 142

1.167

$\mathrm{R} 1=0.0297, \mathrm{wR} 2=0.0804$

$\mathrm{R} 1=0.0300, \mathrm{wR} 2=0.0806$

0.417 and -0.534 e. $\AA^{-3}$
$99.7 \%$

Semi-empirical from equivalents 0.929 and 0.701

Full-matrix least-squares on $\mathrm{F}^{2}$ 2094 / 0 / 96

1.073

$\mathrm{R} 1=0.0351, \mathrm{wR} 2=0.0993$

$\mathrm{R} 1=0.0353, \mathrm{wR} 2=0.0996$

0.530 and -0.323 e. $\AA^{-3}$ 


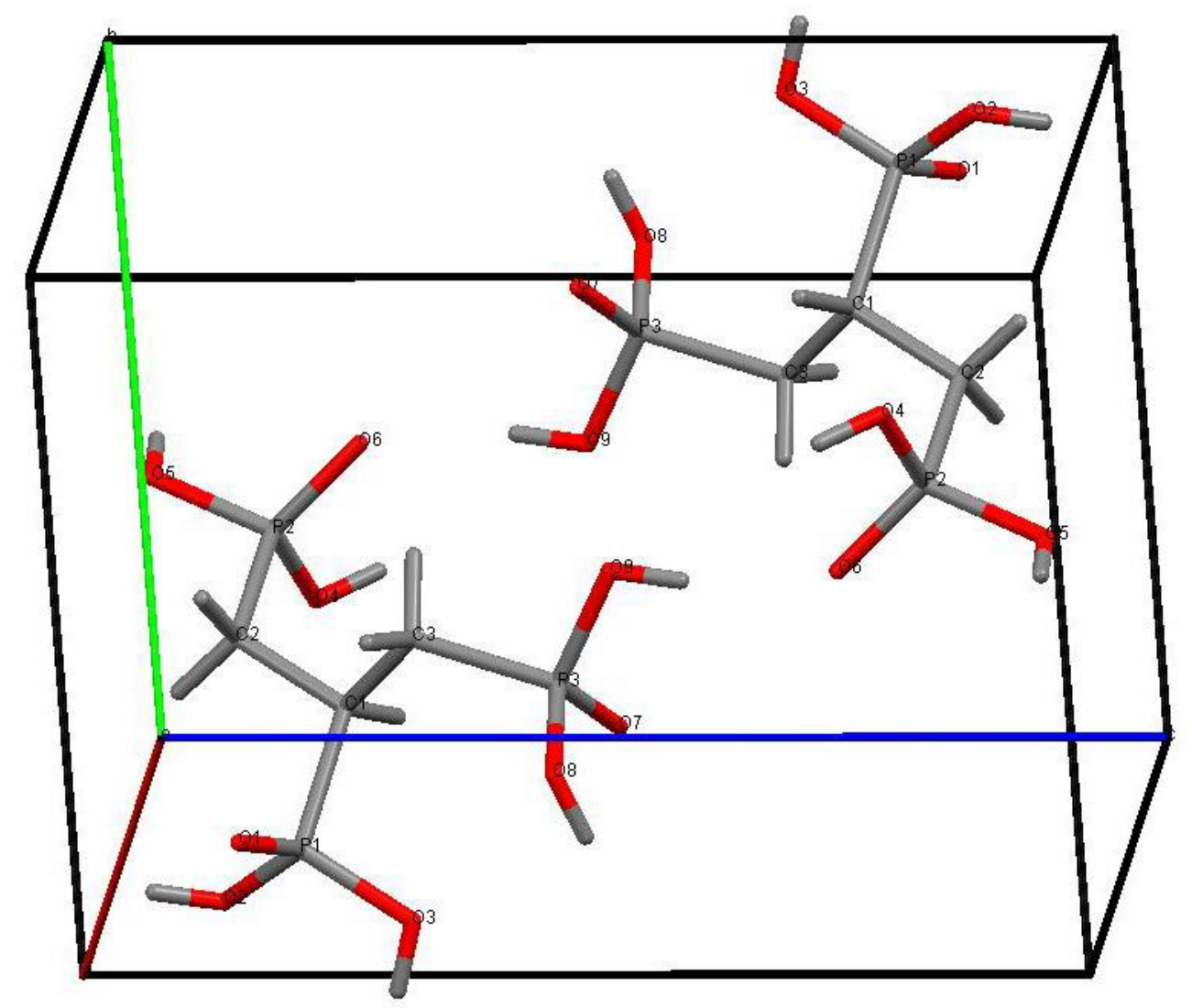

Figure 42: C3 Crystal structure as determined by single crystal XRD

Table 2: $\mathrm{C} 3$ crystal atomic coordinates ( $\left.\times 10^{4}\right)$ and equivalent isotropic displacement parameters $\left(\AA^{2} \times 10^{3}\right)$. $\mathrm{U}(\mathrm{eq})$ is defined as one third of the trace of the orthogonalized $\mathrm{U}^{\mathrm{ij}}$ tensor.

\begin{tabular}{lrrrr}
\hline & $\mathrm{x}$ & $\mathrm{y}$ & $\mathrm{z}$ & $\mathrm{U}(\mathrm{eq})$ \\
\hline $\mathrm{C}(1)$ & $3700(4)$ & $7417(3)$ & $7548(2)$ & $8(1)$ \\
$\mathrm{C}(2)$ & $3263(4)$ & $6273(3)$ & $8529(2)$ & $10(1)$ \\
$\mathrm{C}(3)$ & $5902(4)$ & $7185(3)$ & $7045(2)$ & $9(1)$ \\
$\mathrm{O}(1)$ & $6936(3)$ & $10459(2)$ & $9021(1)$ & $11(1)$ \\
$\mathrm{O}(2)$ & $2082(3)$ & $9664(2)$ & $8746(1)$ & $11(1)$ \\
$\mathrm{O}(3)$ & $3933(3)$ & $10568(2)$ & $7061(1)$ & $11(1)$ \\
$\mathrm{O}(4)$ & $-1394(3)$ & $4158(2)$ & $7264(1)$ & $12(1)$ \\
$\mathrm{O}(5)$ & $987(3)$ & $3200(2)$ & $9029(1)$ & $12(1)$ \\
$\mathrm{O}(6)$ & $2361(3)$ & $3189(2)$ & $7075(1)$ & $10(1)$ \\
$\mathrm{O}(7)$ & $3572(3)$ & $7663(2)$ & $4823(1)$ & $11(1)$ \\
$\mathrm{O}(8)$ & $7973(3)$ & $9847(2)$ & $5940(1)$ & $12(1)$ \\
$\mathrm{O}(9)$ & $7631(3)$ & $6800(2)$ & $5190(1)$ & $12(1)$ \\
$\mathrm{P}(1)$ & $4302(1)$ & $9658(1)$ & $8158(1)$ & $7(1)$ \\
$\mathrm{P}(2)$ & $1259(1)$ & $4058(1)$ & $7901(1)$ & $8(1)$ \\
$\mathrm{P}(3)$ & $6147(1)$ & $7913(1)$ & $5654(1)$ & $7(1)$ \\
& & & & \\
\hline
\end{tabular}


Table 3: C3 crystal bond lengths $[\AA ̊ \AA]$ and angles $\left[{ }^{\circ}\right]$.

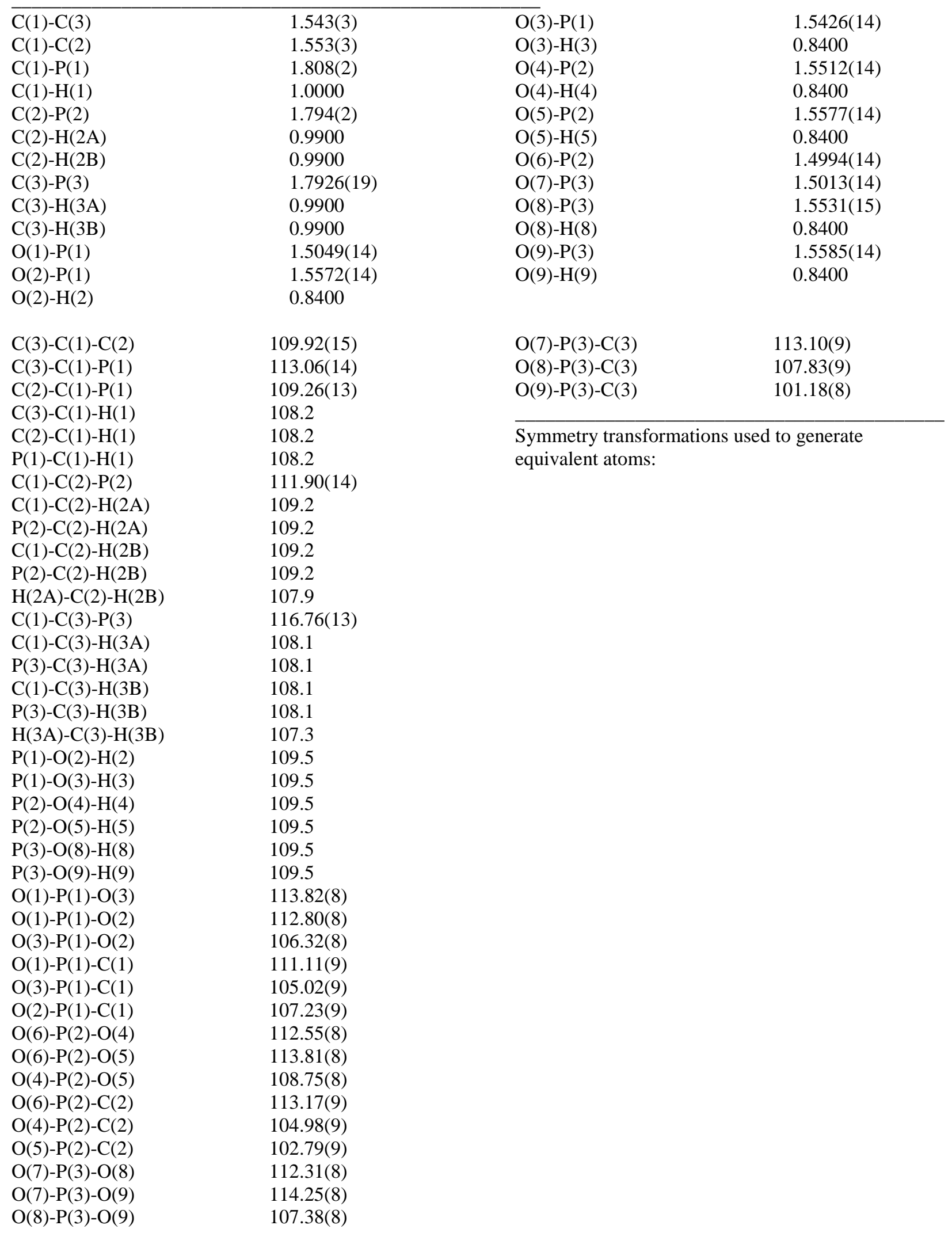


Table 4: C3 crystal anisotropic displacement parameters $\left(\AA^{2} \times 1^{3}\right)$. The anisotropic displacement factor exponent takes the form: $-2 \pi^{2}\left[h^{2} a^{* 2} U^{11}+\ldots+2 h k a^{*} b^{*} U^{12}\right]$

\begin{tabular}{lcccccc}
\hline & $\mathrm{U}^{11}$ & $\mathrm{U}^{22}$ & $\mathrm{U}^{33}$ & $\mathrm{U}^{23}$ & $\mathrm{U}^{13}$ & $\mathrm{U}^{12}$ \\
\hline $\mathrm{C}(1)$ & $9(1)$ & $6(1)$ & $9(1)$ & $2(1)$ & $3(1)$ & $3(1)$ \\
$\mathrm{C}(2)$ & $11(1)$ & $8(1)$ & $9(1)$ & $2(1)$ & $2(1)$ & $2(1)$ \\
$\mathrm{C}(3)$ & $11(1)$ & $9(1)$ & $9(1)$ & $3(1)$ & $4(1)$ & $5(1)$ \\
$\mathrm{O}(1)$ & $11(1)$ & $9(1)$ & $10(1)$ & $1(1)$ & $3(1)$ & $2(1)$ \\
$\mathrm{O}(2)$ & $12(1)$ & $14(1)$ & $10(1)$ & $3(1)$ & $4(1)$ & $6(1)$ \\
$\mathrm{O}(3)$ & $17(1)$ & $10(1)$ & $12(1)$ & $4(1)$ & $7(1)$ & $9(1)$ \\
$\mathrm{O}(4)$ & $11(1)$ & $12(1)$ & $11(1)$ & $-2(1)$ & $1(1)$ & $5(1)$ \\
$\mathrm{O}(5)$ & $13(1)$ & $9(1)$ & $11(1)$ & $2(1)$ & $3(1)$ & $0(1)$ \\
$\mathrm{O}(6)$ & $12(1)$ & $9(1)$ & $12(1)$ & $3(1)$ & $4(1)$ & $5(1)$ \\
$\mathrm{O}(7)$ & $11(1)$ & $10(1)$ & $10(1)$ & $2(1)$ & $2(1)$ & $4(1)$ \\
$\mathrm{O}(8)$ & $10(1)$ & $9(1)$ & $17(1)$ & $5(1)$ & $2(1)$ & $2(1)$ \\
$\mathrm{O}(9)$ & $17(1)$ & $14(1)$ & $12(1)$ & $5(1)$ & $8(1)$ & $10(1)$ \\
$\mathrm{P}(1)$ & $8(1)$ & $6(1)$ & $8(1)$ & $2(1)$ & $3(1)$ & $3(1)$ \\
$\mathrm{P}(2)$ & $8(1)$ & $6(1)$ & $9(1)$ & $2(1)$ & $2(1)$ & $2(1)$ \\
$\mathrm{P}(3)$ & $8(1)$ & $7(1)$ & $8(1)$ & $2(1)$ & $3(1)$ & $3(1)$ \\
\hline
\end{tabular}

Table 5: C3 crystal hydrogen coordinates $\left(x 1^{4}\right)$ and isotropic displacement parameters $\left(\AA^{2} \times 10^{3}\right)$.

\begin{tabular}{|c|c|c|c|c|}
\hline & $\mathrm{x}$ & $\mathrm{y}$ & $\mathrm{z}$ & $\mathrm{U}(\mathrm{eq})$ \\
\hline $\mathrm{H}(1)$ & 2080 & 7008 & 6882 & 10 \\
\hline $\mathrm{H}(2 \mathrm{~A})$ & 2440 & 6768 & 9069 & 12 \\
\hline $\mathrm{H}(2 \mathrm{~B})$ & 4954 & 6295 & 9011 & 12 \\
\hline $\mathrm{H}(3 \mathrm{~A})$ & 5687 & 5931 & 6944 & 11 \\
\hline $\mathrm{H}(3 \mathrm{~B})$ & 7559 & 7815 & 7650 & 11 \\
\hline $\mathrm{H}(2)$ & 2581 & 9691 & 9485 & 16 \\
\hline $\mathrm{H}(3)$ & 3327 & 11352 & 7206 & 17 \\
\hline $\mathrm{H}(4)$ & -1918 & 3562 & 6575 & 17 \\
\hline $\mathrm{H}(5)$ & -249 & 2246 & 8834 & 18 \\
\hline $\mathrm{H}(8)$ & 7197 & 10463 & 5597 & 19 \\
\hline $\mathrm{H}(9)$ & 7793 & 7003 & 4511 & 19 \\
\hline
\end{tabular}


Table 6: Table of representative distances $(\AA)$ and bond angles $\left(^{\circ}\right)$ of atoms involved in hydrogen bonds in the structure of $\mathrm{C} 3$ as determined by XRD

\begin{tabular}{lcccc}
\hline $\mathrm{D}-\mathrm{H} \ldots \mathrm{A}$ & $\mathrm{d}(\mathrm{D}-\mathrm{H})$ & $\mathrm{d}(\mathrm{H} \ldots \mathrm{A})$ & $\mathrm{d}(\mathrm{D} \ldots \mathrm{A})$ & $<(\mathrm{DHA})$ \\
\hline $\mathrm{O}(2)-\mathrm{H}(2) \ldots \mathrm{O}(1) \# 1$ & 0.84 & 1.72 & $2.5541(19)$ & 170.2 \\
$\mathrm{O}(3)-\mathrm{H}(3) \ldots \mathrm{O}(6) \# 2$ & 0.84 & 1.77 & $2.5744(19)$ & 160.8 \\
$\mathrm{O}(4)-\mathrm{H}(4) \ldots \mathrm{O}(7) \# 3$ & 0.84 & 1.73 & $2.556(2)$ & 169.0 \\
$\mathrm{O}(5)-\mathrm{H}(5) \ldots \mathrm{O}(1) \# 4$ & 0.84 & 1.86 & $2.651(2)$ & 156.3 \\
$\mathrm{O}(8)-\mathrm{H}(8) \ldots \mathrm{O}(7) \# 5$ & 0.84 & 1.80 & $2.614(2)$ & 161.4 \\
$\mathrm{O}(9)-\mathrm{H}(9) \ldots \mathrm{O}(6) \# 6$ & 0.84 & 1.82 & $2.6372(19)$ & 164.4 \\
\hline
\end{tabular}

Symmetry transformations used to generate equivalent atoms:

$\# 1-\mathrm{x}+1,-\mathrm{y}+2,-\mathrm{z}+2 \quad \# 2 \mathrm{x}, \mathrm{y}+1, \mathrm{z} \quad \# 3-\mathrm{x},-\mathrm{y}+1,-\mathrm{z}+1$

$\# 4 \mathrm{x}-1, \mathrm{y}-1, \mathrm{z} \quad \# 5-\mathrm{x}+1,-\mathrm{y}+2,-\mathrm{z}+1 \quad \# 6-\mathrm{x}+1,-\mathrm{y}+1,-\mathrm{z}+1$

All hydrogen bonding C3 is intermolecular. There is no evidence of intramolecular hydrogen bonding in the solved crystal.

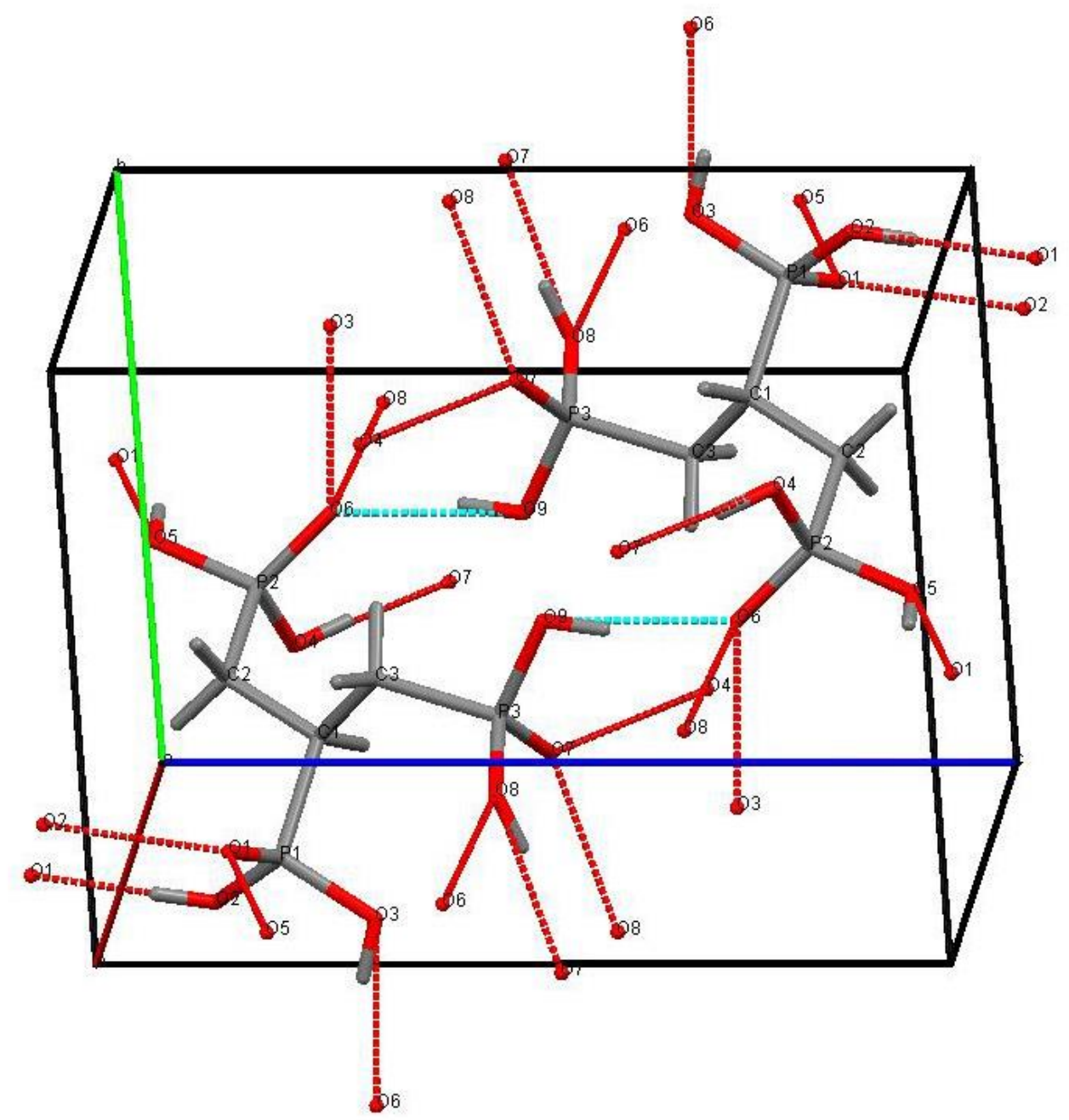

Figure 43a: C3 Crystal structure as determined by single crystal XRD with Hydrogen bonds highlight 


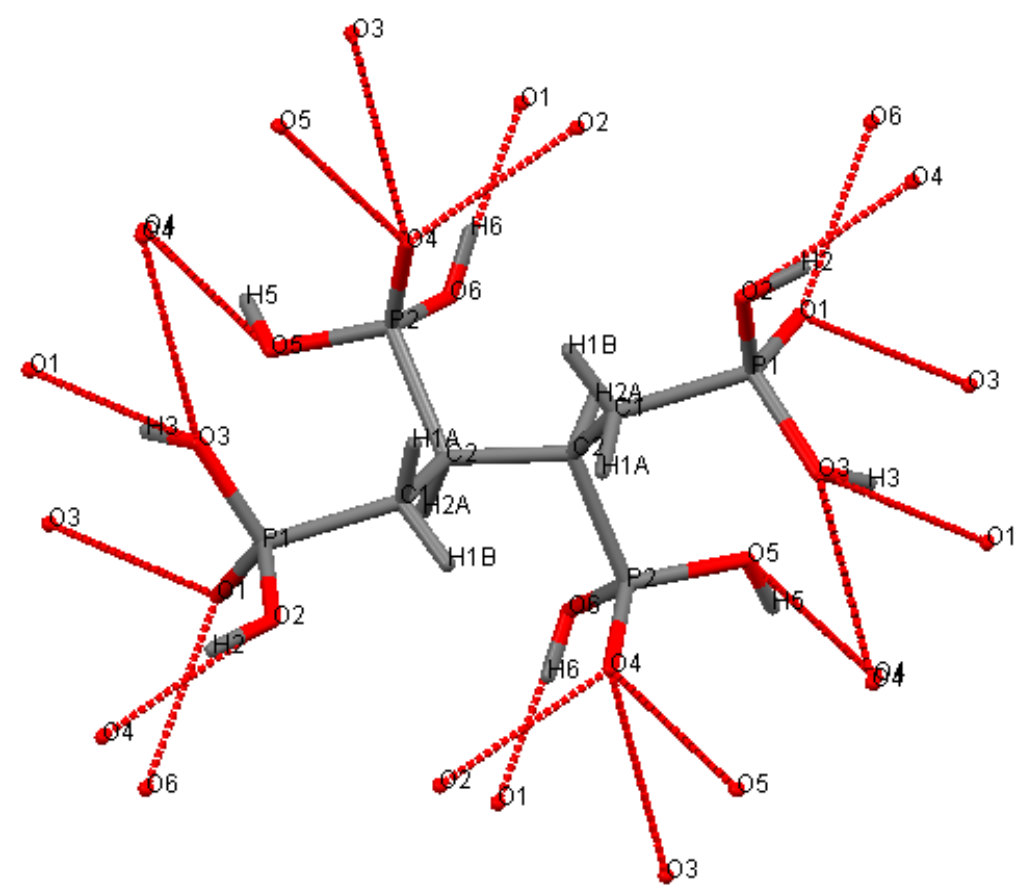

Figure 44b: C4 Crystal structure as determined by single crystal XRD with Hydrogen bonds highlight

Table 7: $\mathbf{C} 4$ crystal Atomic coordinates $\left(x 1^{4}\right)$ and equivalent isotropic displacement parameters $\left(\AA^{2} \times 10^{3}\right)$. $\mathrm{U}(\mathbf{e q})$ is defined as one third of the trace of the orthogonalized $\mathrm{U}^{\mathrm{ij}}$ tensor.

\begin{tabular}{lrrrr}
\hline & $\mathrm{x}$ & $\mathrm{y}$ & $\mathrm{z}$ & $\mathrm{U}(\mathrm{eq})$ \\
\hline $\mathrm{C}(1)$ & $4460(2)$ & $985(4)$ & $1570(2)$ & $15(1)$ \\
$\mathrm{C}(2)$ & $4579(1)$ & $3391(4)$ & $2102(2)$ & $13(1)$ \\
$\mathrm{O}(1)$ & $3611(1)$ & $2825(3)$ & $-167(1)$ & $21(1)$ \\
$\mathrm{O}(2)$ & $4084(1)$ & $-1502(3)$ & $40(1)$ & $23(1)$ \\
$\mathrm{O}(3)$ & $2832(1)$ & $-77(4)$ & $726(2)$ & $24(1)$ \\
$\mathrm{O}(4)$ & $3417(1)$ & $2349(3)$ & $3262(1)$ & $17(1)$ \\
$\mathrm{O}(5)$ & $2946(1)$ & $4775(4)$ & $1737(1)$ & $21(1)$ \\
$\mathrm{O}(6)$ & $3937(1)$ & $6589(3)$ & $3156(1)$ & $19(1)$ \\
$\mathrm{P}(1)$ & $3703(1)$ & $691(1)$ & $469(1)$ & $16(1)$ \\
$\mathrm{P}(2)$ & $3659(1)$ & $4236(1)$ & $2620(1)$ & $13(1)$ \\
\hline
\end{tabular}


Table 8: $\mathbf{C} 4$ crystal bond lengths $[\AA]$ and angles $\left[{ }^{\circ}\right]$.

\begin{tabular}{llll}
\hline $\mathrm{C}(1)-\mathrm{C}(2)$ & $1.550(3)$ & $\mathrm{O}(2)-\mathrm{H}(2)$ & 0.8400 \\
$\mathrm{C}(1)-\mathrm{P}(1)$ & $1.781(3)$ & $\mathrm{O}(3)-\mathrm{P}(1)$ & $1.5519(19)$ \\
$\mathrm{C}(1)-\mathrm{H}(1 \mathrm{~A})$ & 0.9900 & $\mathrm{O}(3)-\mathrm{H}(3)$ & 0.8400 \\
$\mathrm{C}(1)-\mathrm{H}(1 \mathrm{~B})$ & 0.9900 & $\mathrm{O}(4)-\mathrm{P}(2)$ & $1.5021(18)$ \\
$\mathrm{C}(2)-\mathrm{C}(2) \# 1$ & $1.569(4)$ & $\mathrm{O}(5)-\mathrm{P}(2)$ & $1.5440(19)$ \\
$\mathrm{C}(2)-\mathrm{P}(2)$ & $1.815(2)$ & $\mathrm{O}(5)-\mathrm{H}(5)$ & 0.8400 \\
$\mathrm{C}(2)-\mathrm{H}(2 \mathrm{~A})$ & 1.0000 & $\mathrm{O}(6)-\mathrm{P}(2)$ & $0.8528(18)$ \\
$\mathrm{O}(1)-\mathrm{P}(1)$ & $1.4983(19)$ & $\mathrm{O}(6)-\mathrm{H}(6)$ & \\
$\mathrm{O}(2)-\mathrm{P}(1)$ & $1.5543(19)$ & &
\end{tabular}




$\begin{array}{ll}\mathrm{C}(2)-\mathrm{C}(1)-\mathrm{P}(1) & 120.50(17) \\ \mathrm{C}(2)-\mathrm{C}(1)-\mathrm{H}(1 \mathrm{~A}) & 107.2 \\ \mathrm{P}(1)-\mathrm{C}(1)-\mathrm{H}(1 \mathrm{~A}) & 107.2 \\ \mathrm{C}(2)-\mathrm{C}(1)-\mathrm{H}(1 \mathrm{~B}) & 107.2 \\ \mathrm{P}(1)-\mathrm{C}(1)-\mathrm{H}(1 \mathrm{~B}) & 107.2 \\ \mathrm{H}(1 \mathrm{~A})-\mathrm{C}(1)-\mathrm{H}(1 \mathrm{~B}) & 106.8 \\ \mathrm{C}(1)-\mathrm{C}(2)-\mathrm{C}(2) \# 1 & 110.91(14) \\ \mathrm{C}(1)-\mathrm{C}(2)-\mathrm{P}(2) & 113.58(16) \\ \mathrm{C}(2) \# 1-\mathrm{C}(2)-\mathrm{P}(2) & 109.8(2) \\ \mathrm{C}(1)-\mathrm{C}(2)-\mathrm{H}(2 \mathrm{~A}) & 107.4 \\ \mathrm{C}(2) \# 1-\mathrm{C}(2)-\mathrm{H}(2 \mathrm{~A}) & 107.4 \\ \mathrm{P}(2)-\mathrm{C}(2)-\mathrm{H}(2 \mathrm{~A}) & 107.4 \\ \mathrm{P}(1)-\mathrm{O}(2)-\mathrm{H}(2) & 109.5 \\ \mathrm{P}(1)-\mathrm{O}(3)-\mathrm{H}(3) & 109.5 \\ \mathrm{P}(2)-\mathrm{O}(5)-\mathrm{H}(5) & 109.5 \\ \mathrm{P}(2)-\mathrm{O}(6)-\mathrm{H}(6) & 109.5 \\ \mathrm{O}(1)-\mathrm{P}(1)-\mathrm{O}(3) & 112.47(11) \\ \mathrm{O}(1)-\mathrm{P}(1)-\mathrm{O}(2) & 113.78(11) \\ \mathrm{O}(3)-\mathrm{P}(1)-\mathrm{O}(2) & 107.38(12) \\ \mathrm{O}(1)-\mathrm{P}(1)-\mathrm{C}(1) & 115.17(12) \\ \mathrm{O}(3)-\mathrm{P}(1)-\mathrm{C}(1) & 106.92(12) \\ \mathrm{O}(2)-\mathrm{P}(1)-\mathrm{C}(1) & 100.12(11) \\ \mathrm{O}(4)-\mathrm{P}(2)-\mathrm{O}(5) & 113.76(11) \\ \mathrm{O}(4)-\mathrm{P}(2)-\mathrm{O}(6) & 112.93(10) \\ \mathrm{O}(5)-\mathrm{P}(2)-\mathrm{O}(6) & 108.72(11) \\ \mathrm{O}(4)-\mathrm{P}(2)-\mathrm{C}(2) & 112.30(11) \\ \mathrm{O}(5)-\mathrm{P}(2)-\mathrm{C}(2) & 103.61(11) \\ \mathrm{O}(6)-\mathrm{P}(2)-\mathrm{C}(2) & 104.73(11) \\ & \end{array}$

Symmetry transformations used to generate equivalent atoms:

\#1 - $\mathrm{x}+1, \mathrm{y},-\mathrm{z}+1 / 2$ 
Table 9: $\mathbf{C} 4$ crystal anisotropic displacement parameters $\left(\AA^{2} \times 10^{3}\right)$. The anisotropic displacement factor exponent takes the form: $-2 \square^{2}\left[h^{2} a^{* 2} U^{11}+\ldots+2 h k a^{*} b^{*} U^{12}\right]$.

\begin{tabular}{lcccccc}
\hline & $\mathrm{U}^{11}$ & $\mathrm{U}^{22}$ & $\mathrm{U}^{33}$ & $\mathrm{U}^{23}$ & $\mathrm{U}^{13}$ & $\mathrm{U}^{12}$ \\
\hline $\mathrm{C}(1)$ & $17(1)$ & $16(1)$ & $12(1)$ & $-3(1)$ & $1(1)$ & $3(1)$ \\
$\mathrm{C}(2)$ & $11(1)$ & $15(1)$ & $13(1)$ & $0(1)$ & $3(1)$ & $1(1)$ \\
$\mathrm{O}(1)$ & $22(1)$ & $25(1)$ & $15(1)$ & $2(1)$ & $4(1)$ & $2(1)$ \\
$\mathrm{O}(2)$ & $25(1)$ & $24(1)$ & $19(1)$ & $-6(1)$ & $1(1)$ & $4(1)$ \\
$\mathrm{O}(3)$ & $18(1)$ & $26(1)$ & $30(1)$ & $6(1)$ & $4(1)$ & $0(1)$ \\
$\mathrm{O}(4)$ & $15(1)$ & $20(1)$ & $17(1)$ & $1(1)$ & $5(1)$ & $-2(1)$ \\
$\mathrm{O}(5)$ & $17(1)$ & $27(1)$ & $17(1)$ & $-2(1)$ & $1(1)$ & $10(1)$ \\
$\mathrm{O}(6)$ & $26(1)$ & $16(1)$ & $18(1)$ & $-3(1)$ & $10(1)$ & $-2(1)$ \\
$\mathrm{P}(1)$ & $16(1)$ & $18(1)$ & $12(1)$ & $-2(1)$ & $2(1)$ & $1(1)$ \\
$\mathrm{P}(2)$ & $14(1)$ & $14(1)$ & $12(1)$ & $0(1)$ & $4(1)$ & $1(1)$ \\
\hline
\end{tabular}

Table 10: Hydrogen coordinates $\left(x_{10}^{4}\right)$ and isotropic displacement parameters $\left(\AA^{2} \times 10^{3}\right)$.

\begin{tabular}{lrrrc}
\hline & $x$ & $y$ & $z$ & $U(e q)$ \\
\hline & & & & \\
$H(1 A)$ & 4302 & -195 & 2020 & 18 \\
$H(1 B)$ & 5033 & 516 & 1445 & 18 \\
$\mathrm{H}(2 \mathrm{~A})$ & 4650 & 4630 & 1622 & 16 \\
$\mathrm{H}(2)$ & 3799 & -1769 & -513 & 35 \\
$\mathrm{H}(3)$ & 2443 & 885 & 487 & 37 \\
$\mathrm{H}(5)$ & 2574 & 5673 & 1899 & 31 \\
$\mathrm{H}(6)$ & 3805 & 6549 & 3700 & 29 \\
\hline
\end{tabular}


Table 11: Hydrogen bonds for $\mathrm{C} 4$ [ $\AA^{\mathrm{A}}$ and ${ }^{\circ}$ ].

\begin{tabular}{lcccc}
\hline D-H...A & d(D-H) & d(H...A & $\mathrm{d}(\mathrm{D} \ldots \mathrm{A})$ & $<(\mathrm{DHA})$ \\
\hline $\mathrm{O}(2)-\mathrm{H}(2) \ldots \mathrm{O}(4) \# 2$ & 0.84 & 1.76 & $2.588(3)$ & 167.8 \\
$\mathrm{O}(3)-\mathrm{H}(3) \ldots \mathrm{O}(1) \# 3$ & 0.84 & 1.79 & $2.593(3)$ & 159.1 \\
$\mathrm{O}(5)-\mathrm{H}(5) \ldots \mathrm{O}(4) \# 4$ & 0.84 & 1.80 & $2.595(2)$ & 156.3 \\
$\mathrm{O}(6)-\mathrm{H}(6) \ldots \mathrm{O}(1) \# 5$ & 0.84 & 1.74 & $2.560(3)$ & 166.2
\end{tabular}

Symmetry transformations used to generate equivalent atoms:

\#1 -x+1,y,-z+1/2 \#2 x,-y,z-1/2 \#3-x+1/2,-y+1/2,-z

$\# 4-x+1 / 2, y+1 / 2,-z+1 / 2 \quad \# 5 x,-y+1, z+1 / 2$ 


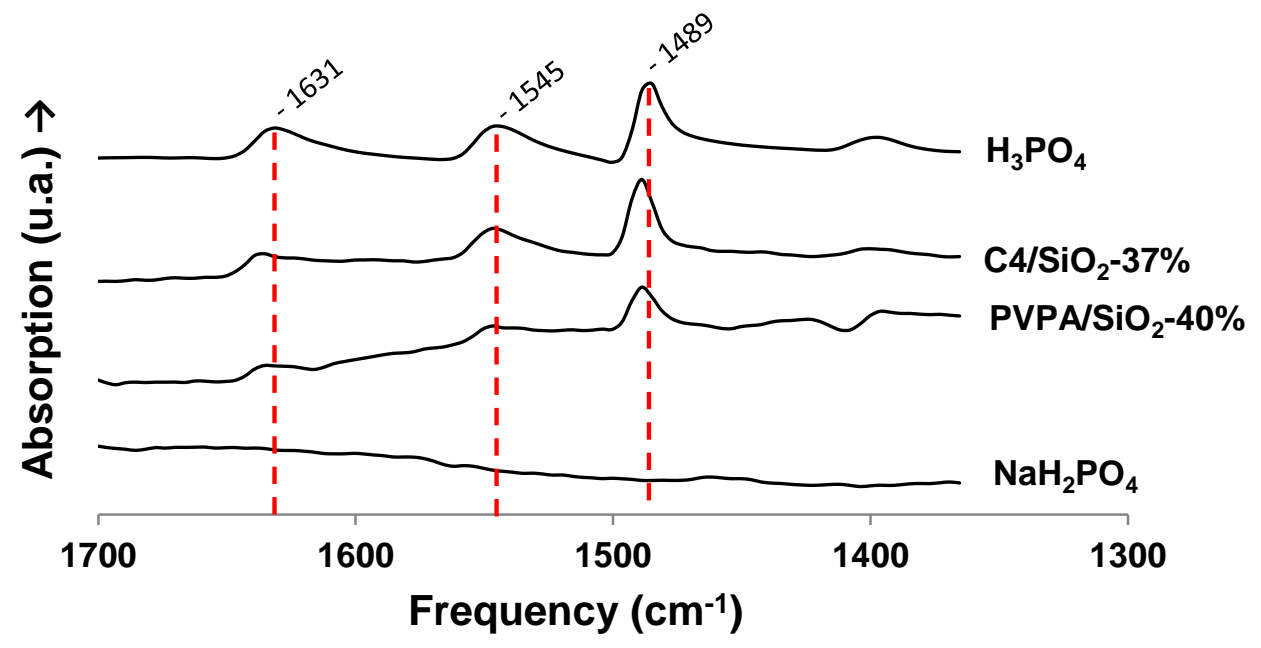

Figure 45: Absorbance of $\mathrm{H}_{3} \mathrm{PO}_{4}, \mathrm{C} 4 / \mathrm{SiO}_{2}-37 \%$, $\mathrm{PVPA} / \mathrm{SiO}_{2}-40 \%$, and $\mathrm{NaH}_{2} \mathrm{PO}_{4}$ treated with an excess of pyridine and degassed overnight at room temperature under vacuum. The background corresponding to the untreated material is subtracted. $\mathrm{H}_{3} \mathrm{PO}_{4}$ spectra is divided 5 fold.

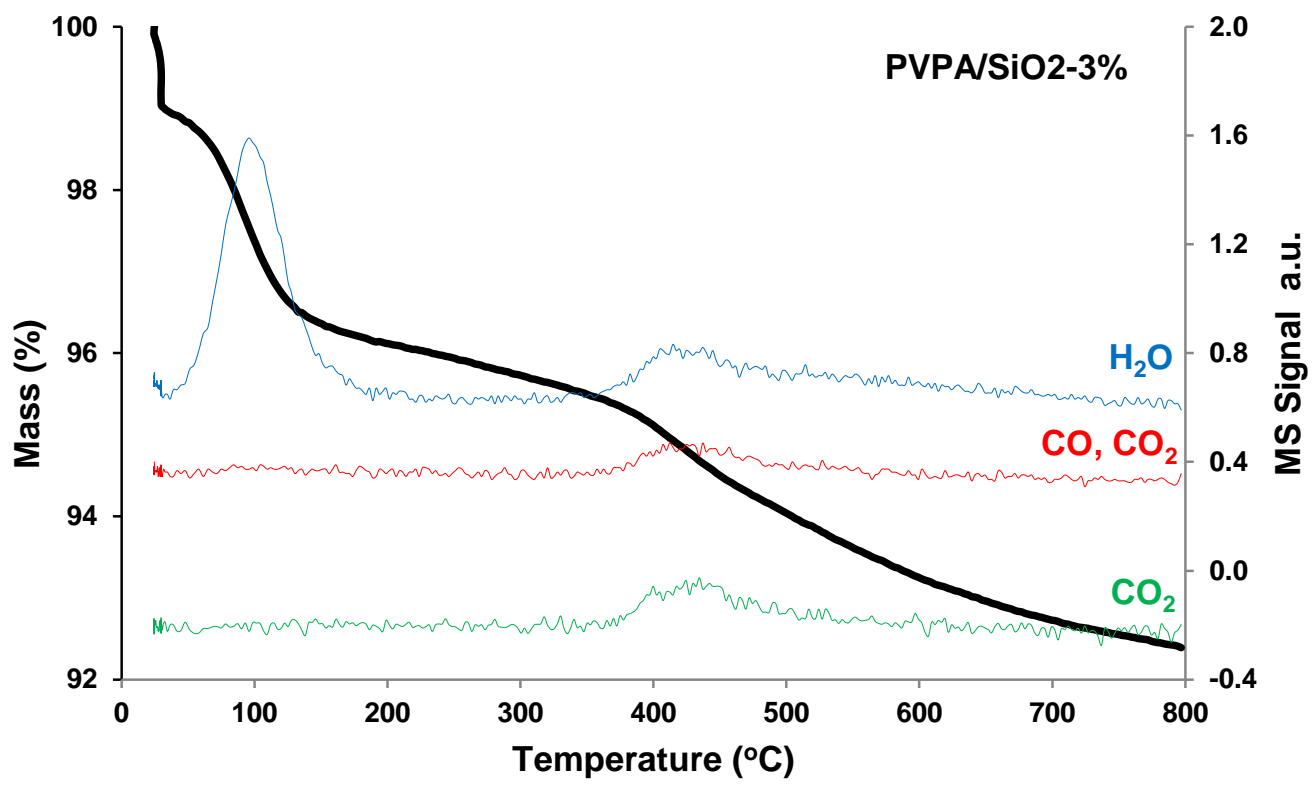

Figure 46: TGA spectra coupled with MS spectroscopy for the samples PVPA/SiO2-3\%, during heating at $5^{\circ} \mathrm{C} \cdot \mathrm{min}^{-1}$. The bold line represents TGA spectra and corresponds to the left axis, whereas the thin line in blue, red and green corresponds MS channels corresponding to the molecular mass $17.97\left(\mathrm{H}_{2} \mathrm{O}\right), 27.93\left(\mathrm{CO}, \mathrm{CO}_{2}\right)$ and $43.91\left(\mathrm{CO}_{2}\right)$ respectively. 


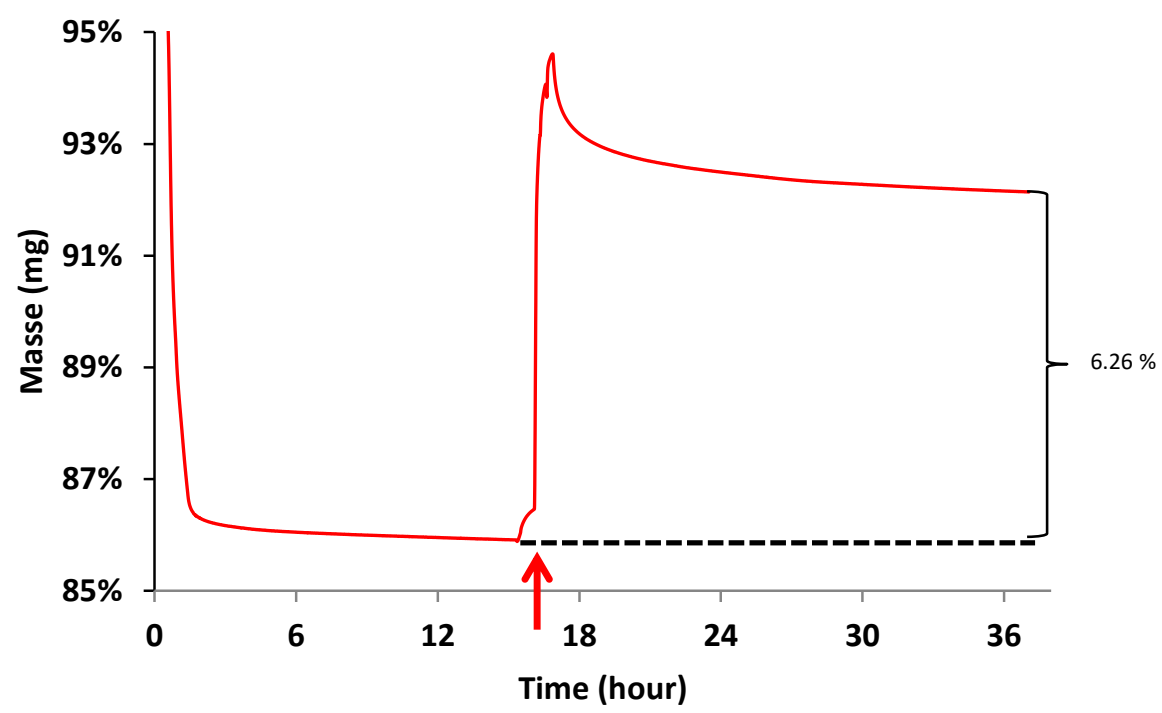

Figure 47: TGA isotherm analysis of DIPA adsorption on $\mathrm{C} 4 / \mathrm{SiO}_{2}-37 \%$ at $150^{\circ} \mathrm{C}$,

after $14.5 \mathrm{~h}$ pre-treatment at $300^{\circ} \mathrm{C}(\mathrm{t} 36)$. The arrow correspond to the time of base probe injection. 